\title{
TARI BALEGA DI TANAH MANANG KARYA SUSAS RITA LORAVIANTI DALAM KAJIAN DRAMATURGI TARI
}

\author{
Mentari Varianda ${ }^{*}$, Sahrul Nazar $^{2^{*}}$, Roza Muliati $^{3^{*}}$ \\ Pengkajian Seni Tari Program Pascasarjana \\ Institut Seni Indonesia Padangpanjang \\ Jl. Bahder Johan, Guguak Malintang, Padangpanjang, Kota Padangpanjang, Kode Pos 27126 \\ Sumatera Barat. Indonesia \\ Email:mentarivarianda9@gmail.com, sharief.kirun@gmail.com,rozamuliati@gmail.com
}

\begin{abstract}
Abstrak
Tari Balega di Tanah Manang merupakan upaya mengekspresikan situasi dan kondisi masyarakat Minangkabau dalam tatanan matrilinial Penelitian ini membahas praktik dramaturgi tari dalam penciptaan Balega di Tanah Manang karya Susas Rita Loravianti. Kerja penciptaan melalui pelahiran bentuk dan konsep dramaturgi yang dilihat dalam praktik dramaturgi. Pola kerja dalam proses penciptaan melalui pandangan koreografer dan dramaturg dalam tugasnya. Adanya praktik dialog antara koreografer dan dramaturg yang dilakukan. Metode penelitian menggunakan pendekatan dramaturgi, yaitu pendekatan yang terpusat pada lingkaran pola kerja yang dilakukan dalam proses kreatif penciptaan dan produksi tari oleh dramaturg dan pendekatan koreografi dalam melihat bentuk karya oleh koreografi.
\end{abstract}

Kata Kunci: balega di tanah manang, dramaturgi.

\begin{abstract}
Balega di Tanah Manang is an attempt to express the situation and condition of Minangkabau society in a matrilineal setting. This study discusses the practice of dance dramaturgy in the creation of Balega di Tanah Manang by Susas Rita Loravianti. The work of creation through the birth of dramaturgical forms and concepts seen in dramaturgical practice. The pattern of work in the creation process through the views of the choreographer and dramaturg in their work. The practice of dialogue between the choreographer and dramaturg is carried out. The research method uses a dramaturgical approach, which is an approach that focuses on the circle of work patterns carried out in the creative process of dance creation and production by dramaturg and a choreographic approach in seeing the form of the work by the choreographer.
\end{abstract}

Keywords: balega di tanah manang, dramaturgy.

\section{PENDAHULUAN}

Proses Seni tari mengantarkan kepada pelahiran pertunjukan dalam gerak sebagai media. Ungkapan perasaan, ekspresi dan pikiran penari yang ingin disampaikan dan dipertunjukan dengan gerak yang indah dan ritmis. Seniman pelaku maupun akademisi tari seringkali melakukan berbagai perubahan terhadap perspektif koreografi dan melakukan berbagai perkembang dalam tata cara sajian dan kemasan. Dalam perkembangannya para seniman tari, koreografer mencari ide dan gagasan melalui fenomena yang terjadi di lingkungan sekitarnya seperti mengangkat tentang budaya dan seni yang berkembang di daerah tempat tinggalnya.

Dalam kaitan ini, 'skill' mencakup kemampuan berpikir, menghayat, dan membentuk yang didalam praktik koreografi diterapkan dalam kegiatan-kegiatan seperti menemukan gagasan/ide, menemukan masalah, membentuk gagasan, mentransformasikan gagasan/ide, dan memecahkan masalah (Murgiyanto, 2016:74). Salah satunya dilihat pada proses penciptaan karya oleh seorang koreografer Sumatera Barat, Susas Rita Loravianti. Berangkat dari pengalaman koreografer dan melihat perempuan dalam sistem matrilineal yang dianut masyarakat Minangkabau serta persoalan perempuan hari ini.

Pengalaman yang dimiliki selama berkesenian, mendorong Loravianti untuk selalu membuat karya tari dengan mengusung fenomena perempuan Minangkabau. Sejak tahun 1992, Loravianti telah melahirkan karya-karya tentang perempuan Minangkabau dalam sudut pandang yang berbeda. Adapun beberapa karya tari yang mengangkat tentang perempuan Minangkabau dalam beberapa tahun terakhir ini diantaranya, karya Tari Garak Nagari 
Perempuan (2014), Rang Rumah (2016) dan Tari Balega Di Tanah Manang (2017, 2018 dan 2019).

Tari Balega Di Tanah Manang merupakan karya hibah multitahun di Institut Seni Indonesia Padangpanjang. Karya ini diciptakan oleh koreografer dalam tiga bentuk karya dengan satu gagasan ide melalui gambaran peristiwa yang berbeda-beda diantaranya, tari Balega Di Tanah Manang karya pertama (2017) memfokuskan tentang perempuan Minangkabau melalui filosofi Bundo Kanduang yang lebih memaparkan kegelisahan perempuan dengan keinginan-keinginan yang ingin dicapai pada saat sekarang ini. Tema matrilineal diangkat dalam bentuk karya tari tradisi dan telah dipentaskan di Yogyakarta. Pada karya ini penari berjumlah 6 orang diantaranya 4 orang perempuan dan 2 orang laki-laki, kemudian menghadirkan seorang aktor perempuan untuk menyampaikan sebuah narasi yang berkaitan dengan konsep perempuan Minangkabau.

Tari Balega Di Tanah Manang karya kedua (2018) memfokuskan tentang peran dan fungsi perempuan Minangkabau melalui konsep filosofi Bundo Kanduang, dimana perempuan dalam kesehariannya yang selalu melakukan tindakan atau perilaku sopan santun sebagai perempuan. Tema matrilineal diangkat dalam bentuk karya modern, karya ini dipentaskan di di Malaysia. Karya ini menghadirkan penari berjumlah 5 orang perempuan dan melakukan gerakan lemah lembut sebagai identitas perempuan Minangkabau.

Tari Balega Di Tanah Manang karya ketiga (2019) memfokuskan tentang nilai-nilai baru perempuan Minangkabau masa kini, yang merupakan hasil reinterpretasi penggarap terhadap fenomena, sejarah dan realitas perempuan Minangkabau masa kini. Penari berjumlah 6 orang dengan koreografer pun ikut menari. Tema matrilineal digarap dalam bentuk tari kontemporer, karya ini dipentaskan di India. Karya yang terakhir ini penggarapannya dilakukan melalui pengembangan koreografi gabungan dari Balega $D i$ Tanah Manang tahun 2017 dan 2018. Pembagian dalam bentuk tiga karya pun memiliki hubungan dan keterkaitan.

Setiap karya tari Balega Di Tanah Manang memiliki persamaan yang dapat di lihat melalui konsep yang dihadirkan oleh koreografer dan dramaturg. Karya tari Balega Di Tanah Manang selalu menggunakan properti piring. Adanya beberapa gerakan dalam koreografi yang hadir dalam setiap karya dan mengalami pengembangan. Perbedaan yang terjadi pada setiap karya Balega Di Tanah Manang dapat dilihat melalui rangkaian peristiwa yang dihadirkan dan dirancang oleh dramaturgi.

Balega Di Tanah Manang tahun 2017 tentang peran penting kaum perempuan dalam persiapan setiap akan dilaksanakannya suatu proses ritual dalam budaya Minangkabau. Pada karya Balega Di Tanah Manang tahun 2018 membedakannya dengan karya sebelumnya terdapat pada garapan yang memainkan tubuh penari perempuan saja dengan sisi lembutnya. Pola koreografinya pun melibatkan pemusik dalam peristiwa karya. Pada karya terakhir Balega Di Tanah Manang 2019 lebih memaparkan secara keseluruhan baik segi pola koreografi dan konsep perempuan yang hadir melalui beberapa properti.

Karya tari berjudul Balega Di Tanah Manang (bahasa Minangkabau) secara sederhana dalam bahasa indonesia sebagai "Perputaran atau aktivitas perempuan Minangkabau di tanah kemenangan". Kata Balega dalam bahasa Minangkabau tidak saja berarti gerak atau aktivitas fisik yang menandai terjadinya peralihan tempat atau kedudukan, melainkan juga berarti niat serta dorongan perasaan (batin) dan motivasi.

Pelahiran rangkaian peristiwa dalam karya tari Balega Di Tanang Manang pun melalui dramaturgi tari yang dirancang oleh dramaturg. Loravianti didukung oleh dramaturg yang bernama Wendy Hs, dimana Wendy merupakan akademisi dan praktisi seni. Melalui kemampuan Wendy merancang dramaturgi, suasana di dalam karya hadir lebih terlihat jelas sesuai dengan keinginan koreografer. Loravianti mengatakan bahwa keinginannya menghadirkan suasana dalam setiap bagian dan adegan peristiwa karyanya melalui dramaturgi. Pelahiran dramaturgi tersebut dihadirkan atas konsep yang dibuat oleh dramaturg yang ia pilih untuk bekerjasama dengannya kemudian menghasilkan suasana yang sampai kepada penonton. Wawancara Loravianti, Selasa, 23 Oktober 2020, Diskusi Dramaturgi, Guguak Melintang.

Penelitian karya tari Balega Di Tanah Manang difokuskan kepada karya ketiga (2019) yang dipentaskan di Universitas Ashoka University, India Tari Balega Di Tanah Manang pada tahun 2019 merupakan karya terbaru yang diciptakan oleh koreografer Loravianti. Tari Balega Di Tanah Manang ini lebih memaparkan secara keseluruhan tentang peran dan fungsi perempuan dalam budaya Minangkabau melalui filosofi Bundo Kanduang. Suatu gambaran tentang tradisi masyarakat Minangkabau apabila ada 
suatu perhelatan dalam sebuah keluarga. Proses penciptaan karya melalui dramaturgi sebagai unsur dalam pertunjukan tari. Dramaturgi adalah jembatan yang menghubungkan gagasan dengan praktek atau hasil karya yang dapat disampaikan kepada penonton. Begitu juga dalam dramaturgi tari merupakan ungkapan perasaan dan pemikiran yang ingin dilahirkan oleh pengkarya ke dalam pertunjukan melalui gerak dan pelahiran itu memberikan kesan tersendiri kepada penonton. Bagaimana proses, cara kerja dan cara melihat ungkapan perasaan seorang koreografer atau pengalaman yang dimiliki dapat dilahirkan melalui gerak yang dipertunjukan dan disampaikan kepada penonton.

Catatan Wulan (2019) membahas tentang "Dramaturgi Tari : Sesuatu Yang Dekat". Dalam catatannya ini, Renee Lebih membahas pandangan yang sama perihal dramaturgi tari oleh ketiga para ahli bidang seni tari. Mengatakan bahwa dalam praktik kerja dramaturgi tari ada yang ingin dibangun di sebuah karya tari, yang diiringi dengan komunikasi antara dua perspektif yaitu perspektif kreator (koreografer) dan perspektif dramaturg. Disini karya terbentuk dari hasil diskusi dari dua pandangan tersebut, namun keputusan akhir tetap berada di tangan koreografer.

Tari Balega Di Tanah Manang merupakan kolaborasi antara koreografer dan dramaturg. Melihat bagaimana proses yang dilakukan antara koreografer dengan dramaturg. Seperti apa konsep yang mereka sepakati dalam pembuatan karya. Seperti apa cara kerja yang dilakukan oleh dramaturg dalam menghasilkan sebuah pertunjukan tari. Sehingga penawaran terhadap konsep dramaturgi dapat menyatu dengan konsep atau ide yang diinginkan koreografer dan dramaturg pun dapat melakukan tugasnya. Dramaturg adalah seorang teman diskusi koreografer, membantu dalam menghadirkan suasana yang sampai kepada penonton. Adanya praktek yang melibatkan dialog antara koreografer dengan dramaturg dalam menciptakan sebuah dramaturgi menghasilkan pertunjukan tari.

Dramaturgi tari pada saat sekarang menarik menjadi perbincangan oleh para seniman, penari, dramaturg tari dan koreografer. Dramaturgi tari melalui pergesekannya lahir karena adanya kebutuhan dalam proses penciptaan tari-tari kontemporer atau eksperimental, adanya kebutuhan untuk menggali ideide baru dan bentuk artistik yang baru. Proses demikian lah maka koreografer membutuhkan seorang partner kerja atau teman diskusi disebut dengan mata kedua dalam proses penciptaan karya. Disitulah kemudian peran dramaturg sebagai tim yang menjembatani praktek seseorang koreografer dengan teori. Dalam praktek dramaturgi tari seorang dramaturg tidak hanya menjembatani tetapi juga terlibat aktif didalam produksi tari.

Hansen (2015: 42) membahas perdebatan tentang dramaturg dalam perannya. Hansen membagi cara pandang yang dapat dilihat dalam praktik dramaturgi tari, cara pandang melalui Agency (kuasa), Awareness (kesadaran), Engagement (keterlibatan). Pernyataan tersebut dapat dilihat bahwa dramaturg tidak hanya bekerja pada ruang atau ketetapan tugas pada teori yang sudah ada, tetapi dramaturg juga ikut berperan aktif sebagai keterlibatan dan kesadarannya dalam setiap produksi tari.

Begitu juga dapat dilihat pada proses penciptaan tari Balega Di Tanah Manang, melihat cara kerja dramaturgi melalui kerjasama antara dramaturg dan koreografer dalam produksi tari. Apakah dramaturg hanya melakukan tugas tugas tertentu sesuai teori dramaturgi sebelumnya, dimana hanya berfokus pada tatanan konsep sebagai perantara gagasan dan praktek atau melakukan cara kerja yang melebihi dari tugas sebagai dramaturg. Fokus utama dramaturg adalah pada tugas-tugas yang menghasilkan kemungkinankemungkinan ini dan bagaimana objek batas terlibat dan berkembang sepanjang proses dalam perwujudan dramaturgi tari.

Membahas tentang dramaturgi dalam disiplin ilmu tari lebih kepada pendekatan, dialog yang terjadi antara koreografer dan dramaturg. Namun dengan pergesekan dramaturgi tari dalam perdebatan itu pun melibatkan seluruh tim produksi untuk pencapaian karya pertunjukan. Berdasarkan uraian diatas, maka terlihat bahwa kesadaran seorang koreografer terhadap pentingnya dramaturgi dalam pelahiran sebuah pertunjukan dan menghadirkan seorang dramaturg untuk berkolaborasi dalam proses penciptaan karya tari pun menarik untuk dibahas. Penelitian ini akan lebih berbicara mengenai praktik dramaturgi tari dalam penciptaan Balega Di Tanah Manang karya Susas Rita Loravianti.

\section{KAJIAN TEORI}

\section{Teori Dramaturgi}

Dramaturgi adalah kumpulan teori tentang seni dramatik atau aktivitas pemanggungan dari teks ide menjadi teks pertunjukan (Luckhurts, 2005: 6). 


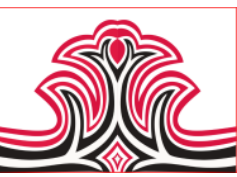

2. Surealisme

Praktik dramaturgi dalam perannya sebagai dramaturg adalah menjadi fasilitator kesadaran dramaturgi dalam sebuah pertunjukan. Praktik dramaturgi terbagi menjadi dua pandangan dimana, pandangan pertama seorang dramaturg hanya memainkan peran sebagai pengatur dan memberi keraguan terhadap koreografer tanpa ikut melibatkan diri dalam karya. Sebaliknya,,pandangan ke dua adalah dramaturg tidak hanya terlibat dengan materi yang diproduksi, tetapi juga dengan kehidupan, pelaku, aktivitas sehari-hari, dan sebagainya. Secara signifikan, metafora spasial secara nyata bekerja dalam contoh-contoh ini. Kekhawatiran tentang pergerakan antara latihan dan refleksi diimbangi dengan pertimbangan tentang di mana dramaturg berdiri, duduk, atau bahkan diletakkan jauh atau dekat dengan proses (Hansen dan Callison, 2015: 40).

\section{METODE PENELITIAN}

\section{Rancangan Penelitian}

Rancangan penelitian merupakan seluruh proses perancangan dan pelaksanaan suatu riset. Rancangan penelitian merupakan prosedur pengumpulan data dan analisis data. Penelitian tari Balega Di Tanah Manang dilakukan dengan cara penelitian kualitatif. Untuk mendapatkan data yang maksimal, sesuai dengan rumusan masalah dengan langkah langkah yang tepat, maka penelitian dengan pendekatan deskriptif analisis.

Penelitian ini juga mengarah kepada pendekatan dramaturgi tari, menurut Arco renz pendekatan dramaturgi lebih menekankan pada proses, cara kerja, cara melihat. Di sana ada keterhubungan (relationship), bagaimana seluruh elemen terhubung bersama (catatan Renee, 2019). Pendekatan ini lebih menjelaskan tentang proses, cara kerja dan cara melihat yang dilakukan oleh seorang dramaturg dalam keterlibatannya pada proses penciptaan karya tari Balega Di Tanah Manang. Di samping itu, pendekatan koreografi juga diperlukan dalam melihat bentuk perwujudan karya tari, bagaimana proses yang dilalui koreografer dalam tahapan proses penciptaan karya tari.

Data-data dan sumber terpercaya digunakan untuk mendeskripsikan secara menyeluruh tentang praktik dramaturgi tari Balega Di Tanah Manang. Berkaitan dengan instrumen penelitian, peneliti sebagai instrumen pertama dengan melakukan berbagai penyesuaian dengan fenomena dan kenyataan yang ditemukan selama proses penelitian.
Gorga : Jurnal Seni Rupa

Volume 10 Nomor 02 Juli-Desember 2021 p-ISSN: 2301-5942 | e-ISSN: 2580-2380

\section{Perenungan (Riset Batin)}

Sumber data merupakan hal yang terpenting dalam suatu penelitian untuk mendapatkan data yang sesuai. Pengumpulan data dalam penelitian ini menggunakan pengumpulan data berupa sumber primer dan sumber sekunder. Sugiyono mengatakan bahwa sumber primer adalah sumber data yang langsung memberikan data kepada pengumpul data dan sumber sekunder merupakan sumber yang tidak langsung memberikan data kepada pengumpul data, misalnya lewat orang lain (Sugiyono, 2007:308)

Sumber data primer dalam penelitian ini terdiri dari penggunaan dokumentasi pertunjukan berupa video dan foto, gagasan yang merupakan hasil pikiran dari beberapa informan seperti koreografer, penari, dramaturg dan komposer. Kemudian sumber data sekunder yang dilakukan dengan melihat arsip atau catatan catatan tentang tari Balega Di Tanah Manang guna untuk membantu dalam penulisan penelitian.

\section{Teknik Pengumpulan Data}

\section{1). Wawancara}

Wawancara merupakan pengumpulan data melalui tanya jawab atau berdialog langsung dengan para narasumber dan informan secara lisan. Wawancara dilakukan untuk mendapatkan informasi secara langsung dengan panduan wawancara kepada narasumber dan informan. Menurut Kerlinger Wawancara merupakan suatu kegiatan tanya jawab dengan tatap muka antara pewawancara dengan yang diwawancarai tentang masalah yang diteliti, dimana pewawancara bermaksud memperoleh persepsi, sikap dan pola pikir dari yang diwawancarai yang relevan dengan masalah yang diteliti, karena wawancara itu dirancang oleh pewawancara maka hasilnya pun dipengaruhi oleh karakteristik pribadi pewawancara (Mulyadi, 2019: 233).

Kerlinger pun membagi wawancara dalam dua bentuk yaitu, wawancara terstruktur dan tidak terstruktur. Wawancara terstruktur apabila pertanyaan dilakukan secara ketat sesuai daftar pertanyaan yang telah disiapkan sedangkan tidak terstruktur apabila pertanyaan yang diajukan bersifat fleksibel tetapi tidak menyimpang dari tujuan wawancara yang telah ditetapkan. Teknik wawancara dilakukan dalam penelitian ini secara langsung melalui gagasan yang diterima dengan cara wawancara tidak terstruktur karena lebih bersifat luwes dan terbuka. Melakukan tanya jawab dan interaksi dengan koreografer, penari dan dramaturgi. 
Wawancara berupa sumber lisan ini dapat membantu memberikan saran dan petunjuk. Melakukan wawancara atau sumber lisan dengan Koreografer Susas Rita Loravianti membahas tentang proses yang dilaluinya dalam menghasilkan ide atau konsep dalam penciptaan karya tari. loravianti pun mengatakan bahwa dalam pemberian gerak dan pola koreografi kepada penari, selalu melakukan tahapan- tahapan tertentu sehingga penari pun dapat memahami setiap hal yang diinginkannya untuk kebutuhan karya tari. kemudian melakukan evaluasi atau koreksi terhadap perkembangan latihan karya tarinya.

Wawancara juga dilakukan dengan dramaturg dalam karya tari Balega Di Tanah Manang yaitu Wendy Hs, membahas tentang tahapan tahapan apa saja yang dilakukannya terhadap proses penciptaan karya Balega Di Tanah Manang yang melibatkan dirinya sebagai seorang dramaturg teater dalam disiplin ilmu tari. Wendy Hs pun menjelaskan bahwa treatment atau kiatkiat yang dilakukannya hampir tidak jauh beda dengan yang sering dilakukannya pada dunia disiplin teater. Memberikan rangsangan terhadap konsep dramaturgi dalam karya ini.

Adapun pihak pihak yang terlibat dan dapat memberikan informasi mengenai karya tari ini seperti para penari, komposer dan pendukung karya lainnya. Salah satunya dapat dilihat pada wawancara Safrini, penari yang sudah lama ikut bergabung dengan Loravianti dalam setiap karya yang diciptakan. Pembahasan lebih kepada rangsangan apa yang dirasakan oleh Safrini selaku penari selama proses latihan penciptaan tari Balega Di Tanah Manang. Safrini pun mengatakan selama berproses dalam penciptaan karya ini, dirinya tidak begitu mengalami kesulitan dalam merespon setiap gerakan-gerakan baru yang diberikan karena dipengaruhi oleh tubuh Minang yang sudah melekat dan mengetahui karakter koreografer.

Wawancara juga dilakukan pada salah satu pemusik yaitu Emri. Wawancara mengenai proses pencarian musik untuk karya tari Balega Di Tanah Manang. Emri mengatakan bahwa musik yang selalu hadir pada garapan ini selalu melihat pada musik yang dirasakan cocok oleh loravianti. Kemudian, pemusik mencoba melakukan hal-hal baru terhadap musik agar musik dalam setiap karya Loravianti memiliki kebaruan tanpa menghilangkan karakter musik yang dimiliki garapan tari Balega Di Tanah Manang.

\section{2). Dokumentasi}

Dokumentasi sangat diperlukan karena bertujuan untuk memberi gambaran yang jelas terhadap data yang sudah diperoleh. Dalam penelitian ini peneliti menggunakan studi dokumentasi dengan penelusuran video untuk melihat bentuk pertunjukan dramaturgi tari Balega Di Tanah Manang. Melihat bentuk pertunjukan tari Balega Di Tanah Manang dari bagian pertama pada tahun 2017, bagian kedua tahun 2018 dan bagian ketiga pada tahun 2019 dengan cara memerhatikan secara rinci dan fokus setiap bagian karya agar bentuk yang dihasilkan oleh koreografer dapat diteliti oleh peneliti. Kemudian mengumpulkan beberapa dokumentasi berupa foto dalam pertunjukan tari Balega Di Tanah Manang.

\section{Teknik Analisis Data}

Teknik analisia data menurut Sugiyono proses mencari dan menyusun secara sistematis data yang diperoleh dari hasil wawancara, catatan dilapangan, dokumentasi dan bahan bahan lain, sehingga dapat mudah dipahami (Sugiyono, 2007: 335). Analisa data lebih kepada mereduksikan data atau memfokuskan data yang sudah didapat baik dari hasil wawancara maupun dokumentasi. Menurut Mishler dengan tujuan akhir penelitian menguraikan dan menjelaskan pola relasi yang hanya dapat dilakukan dengan seperangkat kategori analitik konseptual tertentu (Denzi dan Lincoln, 2009:595).

Mengklasifikasikan berdasarkan kebutuhan data yang diurai melalui bagian konsep dramaturgi dengan cara melihat praktek dialog antara koreografer dengan dramaturg dalam menciptakan dramaturgi menghasilkan pertunjukan. Data-data yang diperoleh kemudian dianalisis yang kemudian dideskripsikan dan dianalisis sesuai dengan bentuk karya ilmiah. Setelah mengklasifikasi dalam bentuk juga menafsirkan atau interpretasi dalam proses kerja yang dilakukan oleh koreografer dalam proses penciptaan karya, menuliskan tahapan - tahapan yang dilalui dan dilakukan seorang koreografer dalam mewujudkan sebuah karya tari. Kemudian menafsirkan proses kerja yang dilakukan seorang dramaturg dalam mengatur atau perantara dalam menerima dan melahirkan konsep koreografer ke dalam praktik dramaturgi dalam sebuah karya tari.

Setelah memaparkan metode yang digunakan dengan membagi dalam tahapan jenis dan sumber data, teknik pengumpulan data dan teknik analisa data dapat disimpulkan bahwa metode ini memberikan gambaran terhadap data, objek penelitian berdasarkan fakta fakta dalam sebuah peristiwa yang dapat memberikan 
pandangan lebih mendalam, menyeluruh mengenai permasalahan yang akan dibahas.

\section{HASIL DAN PEMBAHASA}

\section{Hasil}

\section{1). Konsep Dramaturgi}

Sebuah karya penciptaan seni berawal dari sebuah imajinasi, yang mana imajinasi tersebut berasal dari khayalan, pikiran dari koreografer sendiri. Pada umumnya, koreografer memulai berkarya dengan aktivitas pencarian suatu awal yang memicu penciptaan tari. Koreografer menggunakan berbagai isitilah seperti gagasan awal atau gagasan dasar.

"Gregor zollig dan donald blumenfeld-jones menggunakan isitilah theme (tema), araron copland menyebut germinal idea (gagasan awal), alwin nikolais menggunakan istilah germinal seed (benih awal), hawkins menggunakan istilah germinal material (materi awal), ideas about (ide awal). Apapun pilihan istilahnya, pada dasarnya koreografer memerlukan suatu awal sebagai titik tolak pemikiran dan proses berikutnya" (Yudiaryani, 2017:89).

Dari imajinasilah koreografer dapat membuat sebuah gagasan awal yang dapat dilihat dan dirasakan ke dalam bentuk karya seni tari yang terinspirasi dari berbagai kejadian-kejadian yang terjadi di lingkungan koreografer sendiri dan masyarakat. Dalam perkembangannya, koreografer mencari gagasan melalui fenomena yang terjadi di lingkungan sekitarnya seperti mengangkat tentang budaya dan seni yang berkembang di daerah tempat tinggalnya. Salah satunya dilihat pada proses penciptaan karya oleh seorang koreografer Minangkabau Sumatera Barat Susas Rita Loravianti. Berangkat dari pengalaman koreografer dan melihat perempuan dalam sistem matrilineal yang dianut masyarakat Minangkabau kepada persoalan perempuan hari ini. Hampir semua karya Loravianti mengangkat tentang perempuan dalam kultur Minangkabau yang sistem matrilineal.

Loravianti sendiri lahir dan dibesarkan dalam kultur Minangkabau, sehingga pengalaman sebagai perempuan Minangkabau menjadi gagasan dalam setiap karya yang diciptakannya, perubahan perempuan menjadi gadis, dewasa, ibu. Sejak tahun 1992 awal berkarya telah mengangkat gagasan tentang perempuan, pada karya penciptaan S1 yang berjudul Bungo Larangan menceritakan tentang tidak boleh kawin sesuku tentang konflik bathin seorang perempuan. Karya penciptaan S2 dengan judul Perempuan Dalam Kaba mengambil ikon-ikon perempuan dalam kaba yang ada di Minangkabau.
Ekspresi personal perempuan, memakai ikon Gondan Gandoriah tetapi yang divisualkan adalah konflik diri sebagai perempuan Minangkabau. Kemudian dilihat juga karya S3 judul karya Garak Nagari Perempuan dalam kehidupan sosial, seluruh aktivitas laku perempuan Minangkabau mulai dari sektor ekonomi, rumah tangga, sektor kebudayaan, cerita legenda ditafsir kedalam kehidupan perempuan hari ini.

Karya tari dengan judul Meja Kursi Dengan Segelas Jus yang Tumpah membahas tentang bagaimana perempuan berebut kekuasaan seperti menjadi pemimpin. Beberapa karya yang di ciptakan oleh Loravianti tidak terlepas dari peran dan fungsi perempuan dalam gagasan awal. Loravianti mengatakan bahwa hampir semua karyanya tentang perempuan Minangkabau melalui sistem matrilineal dalam filosofi Bundo Kanduang. Dari sekian banyak filosofi Bundo Kanduang banyak karya yang dapat diceritakan dan dimaknai, karena tidak semua mampu menafsirkan. Seseorang harus benar-benar mengalami, merasakan, mendengarkan baru dapat membuat sebuah karya dan memiliki pengalaman (Wawancara Loravianti, Jumat, 23 Oktober 2020, Diskusi Kekaryaan, Guguak Malintang).

Masyarakat Minangkabau, sebagaimana yang telah diketahui umum, merupakan salah satu dari beberapa kelompok sosial budaya saja di dunia yang bertahan menganut garis keturunan matrilineal atau garis keturunan yang ditentukan berdasarkan garis keturunan ibu/perempuan. Melalui jalannya sistim matrilineal itulah kemudian tercipta berbagai tradisi sosial budaya dalam masyarakat Minangkabau yang unik dan menarik, terutama terkait tentang nilai-nilai perempuan. Perihal itu dapat dilihat mulai dari aspek keberadaan, peran dan fungsi kaum perempuan menurut keyakinan filosofi sosial budaya (perilaku) masyarakat Minangkabau, hingga aspek berbagai pilihan praktik kehidupan atau kerja keseharian (laku) setiap individu perempuan di Minangkabau.

Terdapat dua aspek tentang nilai-nilai perempuan Minangkabau tersebut, yaitu: aspek keyakinan filosofi Minangkabau (ideologis/perilaku sosial perempuan Minangkabau) dan aspek praktik hidup kesehariannya (realitas/laku sehari-hari perempuan Minangkabau), yang keduanya merupakan bagian dari spesifikasi kultural Minangkabau dan perkembangan realitasnya belum banyak diketahui oleh masyarakat luas (Loravianti, 2019:9).

Konsep merupakan sesuatu yang menjadi pokok permasalahan yang akan dikomunikasikan. Untuk 
mendapatkan konsep yang benar-benar menarik, komunikatif dan orisinil sangat sulit, oleh sebab itu sebuah konsep merupakan sesuatu yang berharga. Karya tari Balega Di Tanah Manang ini merupakan suatu ekspresi yang bertolak dari upaya merepresentasikan perkembangan realitas perempuan yang berlaku dalam masyarakat Minangkabau saat ini. Tari Balega Di Tanah Manang dalam pelahirannya memiliki tiga bentuk karya dengan satu konsep melalui peristiwa yang berbeda-beda. Peristiwa yang berbeda tersebut dilihat melalui alur dalam penggarapannya. Karya tari yang diciptakan melalui gabungan penggunaan gerakan yang berasal dari silek dengan gerak tari dan teknik baru diluar silat itu sendiri. Menggabungkan pengaruh unsur tradisi silek Minangkabau dengan dunia tubuh hari ini yang sudah mengalami perkembangan gerak dalam karya tari, menjadi landasan utama dalam tarian ini.

Fenomena yang terjadi di Minangkabau dulunya pencak silat hanya dilakukan oleh laki laki sebagai seni beladiri. Bentuk seni pertunjukan tari Balega Di Tanah Manang pun melibatkan perempuan sebagai koreografer, penari dalam pendukung karya. Persoalan tentang perempuan di Minangkabau dapat dilihat dari berbagai sudut pandang. Namun dalam Tari Balega Di Tanah Manang memiliki konsep ide atau gagasan berbicara tentang sistem matrilineal yang dianut oleh masyarakat Minangkabau, mendekatkannya kepada persoalan perempuan hari ini. Upaya mengekspresikan situasi dan kondisi masyarakat Minangkabau dalam tatanan matrilineal.

Di Minangkabau matrilineal merupakan salah satu adat dan budaya yang menempatkan pihak Perempuan bertindak sebagai pewaris harta pusaka dan kekerabatan, garis keturunan yang diwarisi melalu garis keturunan ibu. Tatanan matrilineal inilah menjadi pengembangan laku, gerak dan bunyi yang berdasarkan pada tradisi silat sebagai pola ekspresi untuk pertunjukan kontemporer dalam karya tari Balega $D i$ Tanah Manang.

Loravianti mengatakan dalam karya tari Balega $D i$ Tanah Manang adanya filosofi perempuan Minangkabau dibuat dalam filosofi Bundo Kanduang terlahir dalam pepatah Limpapeh Rumah Nan Gadang (Bundo kanduang sebagai suri tauladan dalam rumah gadang), Amban Puruak pumpunan jalo Pagangan Kunci (bundo kanduang sebagai penyimpan dan pemelihara harta pusaka) Dan Sumarak Dalam Kampuang Hiasan Dalam Nagari (bundo kanduang bijak dalam penataan rumah tangga, agar terciptanya rumah tangga yang sakinah), Unduang Unduang $\mathrm{Ka}$
Madinah (bundo kanduang mampu mendidik anak keturunannya untuk menunaikan ibadah/mendidik moral dan pengetahuan agama) Payuang Panji Kasarugo (bundo kanduang membimbing dan melindungi kaumnya dengan ilmu pengetahuan dan ilmu agama). Pepatah ini dilahirkan dalam setiap bentuk karya tari Balega Di Tanah Manang. konsep gagasan ini dilahirkan dalam bentuk karya melalui teori dramaturgi tari (Wawancara Loravianti, Jumat, 23 Oktober 2020, Diskusi Kekaryaan, Guguak Melintang).

Setelah melakukan diskusi dalam wawancara terdapat pendapat tentang pelahiran konsep, dibuktikan pada pendapat yang disampaikan oleh koreografer bahwa keinginannya adalah membuat sebuah karya tari yang bergagas atau ide pada perempuan Minangkabau, kemudian seorang sebagai dramaturglah memberikan tawaran-tawaran terhadap konsep, menuliskan pikiran yang diinginkan oleh Loravianti kemudian menafsirkan dan memahami konsep tersebut sehingga dapat dibayangkan dengan apa yang jadi penawarannya, seperti penuturannya berikut: "yang membuat konsep ini sebenarnya Wendy (dramaturg) dan Bunda (Loravianti) maunya perempuan tentang bundo kanduang. Jadi, bundo kanduang itu banyak persoalan dilihat dari semua karya yang telah diciptakan. Bunda mengatakan kepada Wendy apa yang diinginkan. Nanti Wendy mengimajinasikan baru terbentuk gagasan dan ditawarkan olehnya pada bunda. Idenya bunda, Wendy yang membuatkan konsep, menuliskan pikiran bunda tadi, dari konsep yang dibuat Wendy tadi dilihatkan pada bunda dulu, barulah bunda bisa memahami, menafsirkan dan membayangkan apa yang diceritakannya itu" (Wawancara Loravianti, Minggu, 1 Agustus 2021, Kerja Dramaturg, Padangpanjang).

Dari pemaparan Loravianti atas konsep gagasan, dapat dilihat melalui pernyataan yang dikemukakan dramaturg bahwa konsep gagasan merupakan karya yang lahir dari pemikirannya melalui struktur alur dan dramatika pada rangkaian dramaturgi, sedangkan garapan koreografi diimajinasikan oleh Loravianti terhadap penciptaan karya. Konsep gagasan atau ide ini dapat dilihat melalui arah pandang bentuk karya tari Balega Di Tanah Manang. Sebetulnya ide merupakan kepemilikan koreografer dan dramaturg hanya membantu menguatkan dari aspek wacana, teori dan praktiknya. Berdasarkan gagasan isi inilah, proses reinterpretasi atas fenomena dan sejarah penciptaan karya yang telah dilakukan koreografer, yang terwujud dalam bentuk kreasi tersendiri sebagai karya kreatif seni tari, diarahkan untuk membangun makna bersama bagi perempuan Minangkabau di masa kini. Nilai-nilai 
yang disampaikan melalui sosok perempuan yang baru dalam garapan tari Balega Di Tanah Manang.

\section{2). Kerja Penciptaan}

Sebuah karya seni tari dalam pelahirannya melalui dramaturgi, pastilah menghadirkan peran seorang dramaturg. Kesadaran koreografer dalam melibatkan seorang dramaturg dapat dilihat pada proses penciptaan karya tari Balega Di Tanah Manang. Bagaimana seorang koreografer menyampaikan keinginankeinginannya melalui ide atau gagasan konsep kepada dramaturg sebagai teman kerja atau teman diskusi. Konsep yang dirumuskan oleh dramaturg ini lebih mengarahkan tentang pembentukan rangkaian peristiwa yang ingin dihadirkan dalam proses penciptaan. Loravianti pun menghadirkan peran dramaturg, yakni Wendy Hs, seorang akademisi dan praktisi.

Keterlibatan Wendy sebagai dramaturg dalam perannya membuat sebuah tema, judul, alur. Diskusi melalui dialog yang dilakukan dengan Loravianti menghasilkan sesuatu sistem kerja dimana, adanya gagasan kemudian diwujudkan melalui bentuk koreografi dalam gerak, seperti penuturannya berikut:

"Keinginan saya (Wendy) membantu Loravianti dalam mewujudkankan sebuah karya dengan dramaturgi konseptual. Agar karya tari Balega Di Tanah Manang ini berbeda dengan karya sebelumnya. Membuatkan dramatik dan artistik, karena ada hal yang spesifik dari Loravianti dari kekuatan, ketegasan gerak dan Wendy tinggal mengolah artistik, tampilannya dan dialog yang mempertanyakan seperti apa, kenapa" (Wawancara Wendy HS, Kamis, 29 Juli 2021, Keinginan Dramaturg, Padangpanjang).

Kesimpulan diskusi terlihat pada karya koreografi merupakan hasil kerja Loravianti sebagai koreografer. Rangkaian peristiwa yang dihadirkan dalam karya tari merupakan gagasan hasil pemikiran Wendy melalui dramatikanya dalam dramaturgi. Keterlibatnya dalam membuat tema tentang perempuan dan matrilineal. Judul Balega Di Tanah Manang sendiri diartikan oleh Wendy sebagai upaya. Balega dalam pemahamannya adalah bakuliliang (berkeliling). Tanah Manang itu benteng, yakni benteng pertahanan tanah hak pewarisan yang berada pada perempuan. Benteng tersebut adalah perempuan dan tanah. Hak pewarisan ada pada perempuan dan akan diwariskan secara turun temurun.
Menurut Wendy sendiri bahwa di Minangkabau permasalah hak pewarisan tanah atau harta pusaka diturunkan melalui matrilineal. Kepemilikan ini merupakan hak yang dimiliki oleh perempuan dan pengelolahannya. Jadi Balega Di Tanah Manang dapat di artikan sebagai perputaran siklus kehidupan perempuan Minangkabau. Dapat disimpulkan bahwa kolaborasi yang dilakukan dengan praktik dialog antara koreografer dan dramaturg dalam perumusan gagasan ini melalui peran dramaturg merumuskan gagasan, tema, judul dan alur yang akan diciptakan melalui dramatika dalam sebuah karya. Dapat dilihat bahwa Loravianti ingin melahirkan ide melalui peran dan fungsi perempuan melalui filosofi Bundo Kanduang, tugas Wendy membuat sebuah gagasan hak pewarisan melalui garis matrilineal. Dalam teori dramaturgi, seorang dramaturg memiliki tugas-tugas menjembatani antara gagasan dengan praktik. Dramaturg berperan aktif dalam produksi tari. "Pemaparan How Ngean dalam catatan Renee membahas syarat syarat dramaturg tari yang lebih terperinci yaitu mampu mengamati (melihat secara antropologi, sosial, mengkaji kekakuan manusia, membuat catatan tentang apa yang dilihat), bertanya, mengapa dan bagaimana, berdiskusi, tidak mengarahkan kreator (koreografer), memberi opsi-opsi, memancing, mengkritisi, membantu membangun gerak sebagai bahasa, membantu membuat struktur dan memiliki hubungan yang nyaman dengan koreografer (Wulan, 2019).

Berdasarkan pemahaman diatas tugas Wendy membantu Loravianti dalam pelahiran ide dengan membuatkan struktur agar dramaturgi tari Balega Di Tanah Manang memiliki peristiwa atau suasana yang tersusun. Penciptaan karya tari tentu mempunyai metode dan tahapan-tahapan yang dilakukan, agar dapat menghasilkan karya yang baik. Seorang koreografer-penari harus melakukan hal yang sungguhsungguh agar mempermudah mereka dalam berkreativitas untuk mencipta, memahami bagaimana proses-proses yang harus dilalui (Hadi, 2014: 70).

Pada kerja penciptaan ini peran dari masing-masing tim yang terlibat dapat dilihat, pada peran koreografer yang membentuk ide atau gagasan dalam sebuah proses penciptaan. Kemudian, memilih dan membentuk penari yang akan melahirkan karaktek gerak yang diinginkannya. Loravianti mengatakan bahwa dalam proses penciptaan karya dirinya lebih membentuk polapola koreografi dan membentuk musikalitas pada setiap tim yang terlibat dalam pertunjukan karya atau dikenal dengan istilah performer. Wendy pun berperan dalam memberikan stimulus terhadap makna dan ketegasan, 
seperti meyakinkan gerak yang dilakukan itu harus pasti pada setiap prosesnya.

Peran penari pun sangat penting dalam wewujudkan karya tari melalui gerak yang dihasilkan oleh tubuh penari. Penari mencoba untuk menghapal dan mengeksplor dirinya dalam imajinasi pengalaman tubuhnya, sehingga ketika Loravianti memberikan rangsangan terhadap konsep garapan pun penari dapat berimajinasi. Karya tari Balega Di Tanah Manang memiliki proses penciptaan karya yang melalui tahapan yang panjang. Proses yang dapat dilihat dari awal pencarian ide sampai karya dipertunjukan pada penonton, dimana para penonton yang tergabung dalam pengetahuan seni maupun masyarakat awam. Melalui kreatifitasnya Loravianti dapat mewujudkan karya dengan melihat apa yang ada disekitarnya, melalui pengalaman-pengalaman yang ada pada dirinya sendiri.

Dalam proses penciptaan karya tari ada beberapa hal yang harus diperhatikan seperti adanya pengembangan gerak sebagai pijakan dalam melahirkan sebuah gerak tari. Proses kreatif pun diklarifikasikan dalam empat bagian utama yaitu, eksplorasi, improvisasi, komposisi dan evaluasi agar diberi kesempatan untuk berfikir, merasakan dan berimajinasi (Yudiaryani, 2017: 95). Tahapan-tahapan yang dilakukan dalam proses penciptaan adalah:

\section{(1). Persiapan}

Berdasarkan konsep karya yang ingin dilahirkan oleh Loravianti, ada beberapa persiapan yang dilakukan, melakukan komunikasi dengan beberapa pihak yang akan terlibat mampu membantu proses penciptaan karya. Melakukan seleksi atau pemilihan penari sesuai dengan kebutuhan karya dan komunikasi dengan para penata yang dipilih seperti penata musik, penata artistik, penata suara dan lainnya. Proses penciptaan karya seni dibutuhkan tim pendukung untuk mencapai apa yang diharapkan dalam pelahiran bentuk karya. Dalam tari Balega Di Tanah Manang peran seorang penari sangat penting. Melalui tubuh penari maka kontekstual karya dapat dipahami oleh penikmat seni.

Melakukan kerjasama atau diskusi oleh koreografer dan dramaturg sesuai teori dalam dramaturgi tari, maka Dapat dilihat bahwa bagaimana koreografer dan dramaturg menemukan penari- penari yang dibutuhkan dalam pertunjukan karya. Melihat dan menentukan karakter apa saja yang diperlukan dalam pemilihan penari. Berapa orang penari yang dibutuhkan dan gender penari yang diinginkan pun melalui diskusi diantara mereka berdua. Namun hal tersebut hanya dilakukan oleh koreografer dalam menentukan kriteria
Gorga : Jurnal Seni Rupa

Volume 10 Nomor 02 Juli-Desember 2021 p-ISSN: 2301-5942 | e-ISSN: 2580-2380

dan jumlah penari yang diinginkan. Loravianti mengatakan bahwa karya tari ini memerlukan penaripenari yang tidak saja menguasai teknik tari dan memahami fungsi-fungsi gerak dalam tari, namun juga memiliki kemampuan dalam membangun karakter

Penari yang dipilih pun diharapkan memiliki basic gerak tari Minangkabau. Penari berasal dari mahasiswa Institut Seni Indonesia Padangpanjang, beberapa penari juga sering terlibat dalam karya-karya sebelumnya. Penari dalam tari Balega Di Tanah Manang tiap bentuk karya memiliki kecenderungan memilih penari dengan jumlah 5 orang penari, diantaranya dibesarkan dengan tubuh tradisi Minangkabau dan 2 diantaranya memiliki tubuh diluar Minangkabau. Adanya karakter-karakter yang harus dikuasai dan nampak dari ketubuhannya. Mencari penari yang diinginkan oleh Loravianti melalui feeling (rasa), dari caranya bergerak, melakukan gerakan, memulai bergerak itu menjadi dasar sebenarnya ketika mengamati. Beberapa penari dalam karya tari Balega Di Tanah Manang pun memiliki tubuh yang tidak hanya berasal dari tubuh Minang saja, namun ada beberapa penari yang diluar dari tubuh Minang.

Ketika menemukan penari dengan kekuatan dan karakter ketubuhan yang dimiliki dapat membantu Loravianti untuk melatih tubuh penari sehingga memiliki pengembangan dan dasar-dasar tubuh Minangkabau yang diinginkan oleh Loravianti. Safrini yang memiliki tubuh dengan pengalaman tubuh minangkabau mengatakan bahwa sebagai penari dirinya dilatih dengan teknik gerak dasar Minangkabau, kemudian diberikan rangsangan terhadap pengembangan gerak yang membuatnya paham dan mengerti bagaimana karakter gerak yang dimiliki oleh Loravianti (Wawancara Safrini, Minggu, 26 Juli 2021, Pengalaman Penari, Padangpanjang).

Karakter gerak yang dimiliki Loravianti selalu berangkat dari gerak dasar silat dan pengembangannya, sehingga memudahkan Safrini sebagai penari dalam melahirkan setiap gerakan- gerakan dalam keterlibatannya pada proses penciptaan karya. Penari yang diinginkan pun haruslah memiliki musikalitas yang baik, dapat merasakan, mengalami pada setiap bunyi dan sensasi dalam tubuhnya sendiri. 


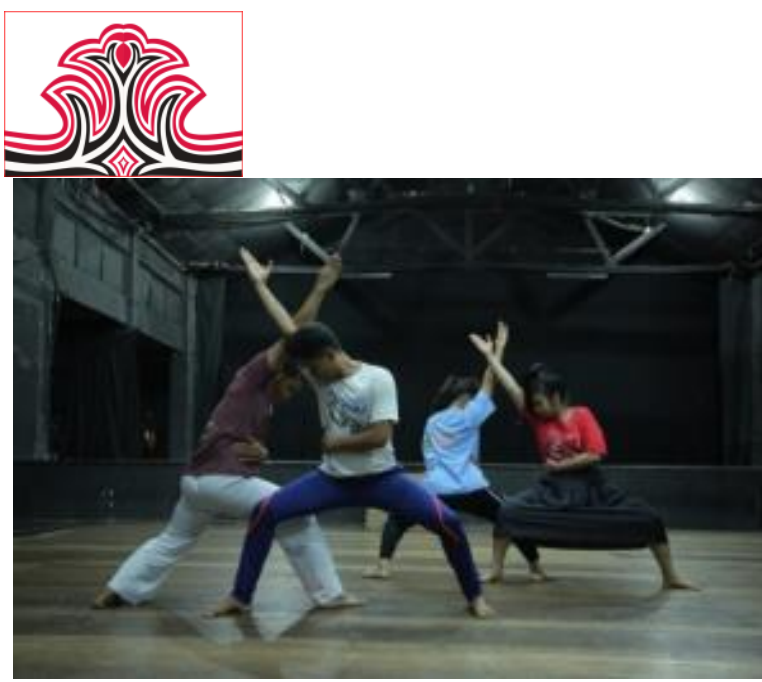

Gambar 1.

Pemilihan Penari yang Menguasai

Gerak Tari Minangkabau

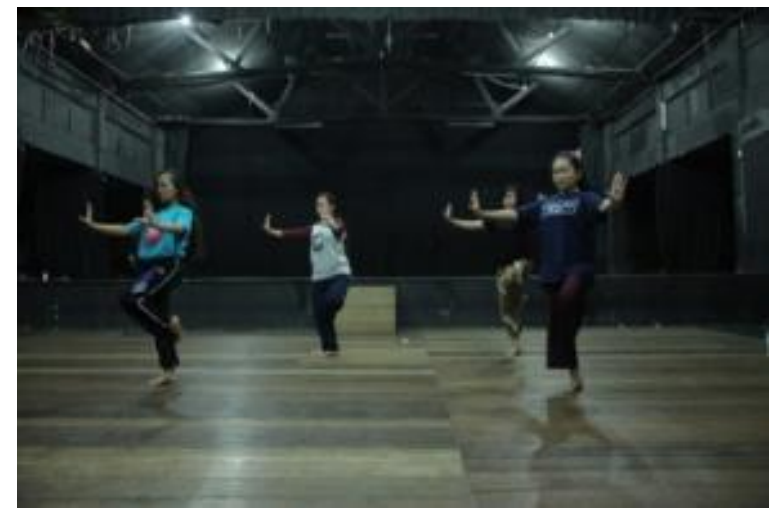

Gambar 2.

Mengenal Karakter Tubuh Penari

dalam Gerak Dasar Minangkabau

Penari yang terpilih sesuai dengan keinginan koreografer dengan memberikan beberapa materi dasar gerak Minangkabau dan memberikan gerak yang pernah diciptakan dalam tari yang diciptakan oleh Loravianti. Penerapan ini bertujuan agar nantinya penari yang ikut terlibat dalam karya Loravianti dapat memiliki karakter perempuan Minangkabau, dan juga dapat memahami gaya yang dimiliki oleh Loravianti. Dalam setiap penari tidak hanya menguasai gerak namun harus menguasai materi dalam olah vokal seperti dendang dan dialog (monolog). Menurut Loravianti penari itu harus bisa menari dengan baik dan memiliki musikalitas yang baik (Wawancara Loravianti, Minggu, 1 Agustus 2021, Metode Seleksi Penari, Guguak Malintang).

Hal ini juga berlaku pada pemilihan pemusik dan pendukung lainnya, dapat dilihat pada pemilihan musik sesuai dengan yang dirasa Loravianti cocok dengan yang dibutuhkannya. Menurut Emri sebagai pemusik dalam karya tari Balega Di Tanah Manang mengatakan bahwa musik yang dilahirkan dalam garapan ini melalui proses pencarian dengan melihat pada karakter gerak dan pola koreografi kemudian disesuaikan dengan keinginan koreografer (Wawancara Emri,
Gorga : Jurnal Seni Rupa

Volume 10 Nomor 02 Juli-Desember 2021

p-ISSN: 2301-5942 | e-ISSN: 2580-2380

Selasa, 27 Juli 2021, Garapan Musik, Guguak Malintang). Apalagi dengan orang-orang mempunyai kedekatan emosional sehingga mereka pun dapat paham atas apa yang ingin dilahirkan oleh Loravianti. Dalam persiapan musik contohnya, memilih seorang komposer dengan kemampuan melahirkan musikmusik yang sesuai dengan perasaan dari seorang koreografer.

\section{(2). Eksplorasi}

Istilah eksplorasi secara harfiah berarti penjelajahan lapangan dengan tujuan memperoleh pengetahuan lebih banyak, kegiatan untuk memperoleh pengalaman baru dari situasi baru. Pada praktik penciptaan tari, eksplorasi dipahami sebagai tindakan penjelajahan dengan rangsangan dan target tertentu (Yudiaryani, 2017:96). Pada karya tari Balega Di Tanah Manang eksplorasi dilakukan dalam latihan-latihan yang melibatkan semua penari dengan tujuan mengeksplorasi kemampuan penari dalam menerjemahkan konsep yang telah digariskan oleh koreografer.

Eksplorasi ini lebih memberikan kesempatan pada penari untuk merespon ruang pergelaran yang telah dipilih dengan menggabungkan atau mengeksplorasi gerak silek yang ada di Minangkabau, khususnya silek tuo, silek luncua dan silek pauah. Tahap eksplorasi dengan upaya Embodyment atau penubuhan kedalam kerja-kerja laboratori gerak distudio. Tahap ini dapat menghasilkan kebutuhan teknik olah tubuh, rangakaian gerak dalam komposisi sebagai wujud capaian dramatikanya dan design artistik panggung pertunjukan.

Manusia melalui media tubuhnya mengalami terhadap ruang, waktu, benda, getaran suara, cahaya, aroma, serta lingkungan sosialnya, bahkan juga bagaimana individu mengalami gerak, suhu, permukaan, aroma, bunyi maupun tegangan, dan sensasi dalam tubuhnya sendiri. Mengalami senantiasa mengalir menuju kesadaran yang menumbuh (Simatupang, 2013: 55). Berdasarkan defenisi tersebut dapat dilihat bahwa tari Balega Di Tanah Manang tubuh sangat berperan penting dalam pelahiran makna melalui gerak. Respon penari dalam pemahaman setiap gerakan dapat memperoleh pengalaman baru, membangun karakter melalui tubuh yang mengalami. Sebagai seorang penari, Ryana adalah salah satu penari yang diandalkan dan terlibat dalam tari Balega Di Tanah Manang. dasar tari yang dikuasainya pun selalu mengarah kepada tari Melayu Deli yang bukan dasar tradisi Minangkabau. 
Ryana mengakui bahwa diberi kepercayaan oleh Loravianti untuk menari membuat dirinya harus berusaha keras dalam memberi warna Minangkabau dalam setiap gerakannya. Seperti penuturannya berikut: "Bunda Oya (Loravianti) memilih saya (Ryana) karena melihat kemampuan dalam meyelaraskan warna Minangkabau dalam gerakan dengan penari lain. Mengajarkan disiplin perihal semua hal apalagi terhadap gerak. Apa yang dikasi pada Ryana seperti dalam ketegasan gerak. Kemudian kepekaan terhadap musik, ritme gerak, tempo dan kekuatan pada kaki seperti Pitunggua. Motivasi yang selalu diberikan pada proses latihan seperti Apapun yang diberikan, gerak apapun yang dibuat, Bunda Oya mengatakan dirinya hanyalah seorang koreografer yang menceritakan tarian ini dan menyampaikan maksud pada penonton adalah penari dan dirinya percaya apa yang diberikan bisa kalian rasakan, maknai dan bisa digambarkan melalui imajinasi dalam peran perempuan melalui gerak sebagai penari" (Wawancara Ryana, Senin, 2 Agustus 2021, Pengalaman Penari, Via Telpon).

Berdasarkan penuturannya terlihat bahwa proses yang dilaluinya dalam mempelajari karakter tubuh Minangkabau bukan hal yang mudah karena tubuh yang dipengaruhi oleh tubuh dari daerah asalnya yaitu Medan Sumatera Utara masih mempengaruhi pengalamannya dalam setiap gerakan. Namun dengan latihan dan mencari-cari kekuatan tubuh Minangkabau selama berproses membuat dirinya bisa memahami dan mengerti akan karakter tubuh Minangkabau yang digarap oleh Loravianti.

Dalam memberikan karakter tubuh Minangkabau pun Loravianti selalu mentransfer proses kerja tubuh yang baik terhadap pengembangan laku dalam segala aspek dasar gerak kepada penari sebagai tahap persiapan penciptaan karya. Sebagai penari Virda pun mengatakan bahwa keterlibatannya dalam proses penciptaan karya tari Balega Di Tanah Manang adalah proses dimana awal pengenalan dirinya terhadap pemahaman tentang proses tari yang bertema, karena selama ini hanya mempelajari tari yang bersifat hiburan (Wawancara Virda, Sabtu, 31 Juli 2021, Pengalaman Penari, Padangpanjang). Selama proses penciptaan ini Virda harus lebih berlatih keras dengan dirinya agar bisa menyeimbangi penari-penari lainnya, belajar dalam memaknai gerak yang dialami oleh tubuhnya.

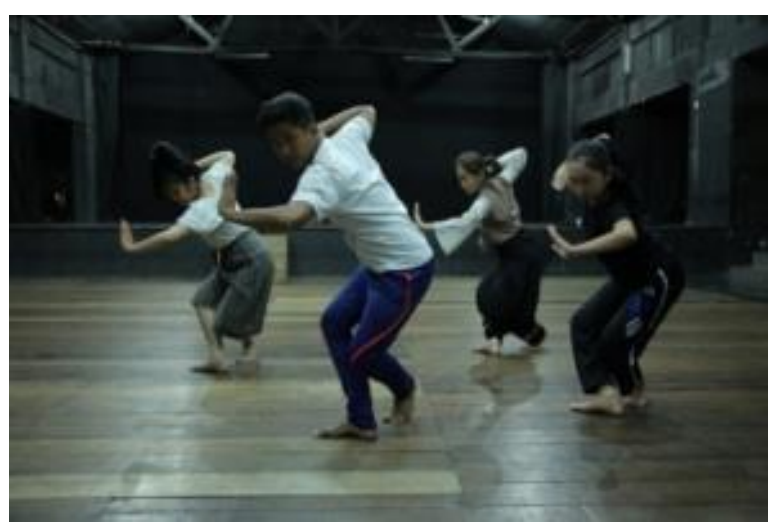

Gambar 3.

Kegiatan Eksplorasi Bentuk Gerak Silek oleh Penari

\section{(3). Improvisasi}

Improvisasi merupakan aktifitas penjelajahan gerak spontan, intuitif dan bebas. Gerak improvisasi dapat distimuli antara lain dengan manipulasi pola gerak, tanggapan panca indera, imajinasi situasi, pernapasan dan imajinasi pemeranan (Yudiaryani, 2017: 97). Pada tahap improvisasi para penari tidak lagi berlatih pada ruang pertunjukan yang telah dipilih, melainkan pada studio. Loravianti memberikan kemampuan terhadap para penari dalam mengelolah daya imajinasi dan daya ingat dengan mengembangkan materi-materi gerak utama yang telah dieksplorasi agar terlihat estetis dan terukur. Dalam struktur yang dirumuskan Wendy, Improvisasi dalam karya tari Balega Di Tanah Manang lebih kepada pengembangan bentuk dan isian menjadi satu kesatuan artistik yang sesuai dengan capaian dramatika pertunjukannya.

Tahapan ini menghasilkan tiga tingkatan skala pertunjukan yaitu pertama skala pertunjukan skala lokal, ditahun pertama penelitian ditingkat provinsi Sumatera Barat. Kedua pertunjukan skala nasional ditahun kedua salah satu kota di pulau Jawa dan ketiga pada tahun ketiga skala internasional dalam event atau festival seni pertunjukan internasional disalah satu negara di India.

\section{(4). Komposisi}

Komposisi dapat dipahami sebagai tindakan penyusunan karya tari sebagai sentral penciptaan. Koreografer menganalisis, dan menginterpretasi materi-materi untuk disusun dalam kesatuan bentuk karya tari yang utuh (Yudiaryani, 2017:99). Isitilah komposisi juga sering disebut pembentukan (forming). Pada tahap pembentukan ini ditambahkan dengan proses seleksi, integritas dan kesatuan sehingga menghasilkan bentuk yang dinamakan tari. Setiap bentuk koreografi, harus dipikirkan secara mendasar seperti aspek kontruksi yang ingin dicapai pada proses penciptaan berlangsung. Sehingga dalam berproses 


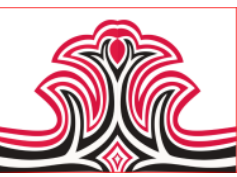

telah tersusun struktur secara signifikansi dan memudahkan kinerja koreografer menuangkan ide sesuai struktur. Menurut Smith " metode kontruksi adalah sebuah metode atau bentuk penyusunan dan pengkombinasiaan dari berbagai elemen untuk mencapai keberhasilan yang harus dipahami bagi seorang penata tari” (Smith, 1989:15). Berdasarkan pendapat tersebut bahwa setiap koreografer tidak hanya memikirkan bentuk pada motif gerak, melain memikirkan aspek kontruksi dalam struktur garapan tari.

Kontruksi akhir yang diwujudkan dalam karya tari Balega Di Tanah Manang dibentuk melalui praktik dialog antara koreografer dengan dramaturg yang dilibatkan. Kontruksi akhir pada karya tari Balega Di Tanah Manang karya pertama pada tahun 2017, karya ini diawali dengan kesan yang diharapkan dari peristiwa adanya posisi yang menunjukan adanya beda wilayah keberadaan (aktifitas) kaum perempuan dan kaum laki-laki sebagai suatu kesatuan wilayah sosialnya (aktifitas kehidupan bersama) menurut Wendy stimulan yang diberikan dengan menyikapi bentuk kesatuan, misalnya keberadaan dapur dan ruang tengah di sebuah Rumah Gadang dalam budaya Minangkabau. Perempuan cenderung berada diwilayah belakang (dapur) sedangkan laki laki cenderung berada di tengah dan halamannya (Wawancara Wendy, Kamis, 29 Juli 2021, Rancangan Dramaturgi, Padangpanjang).

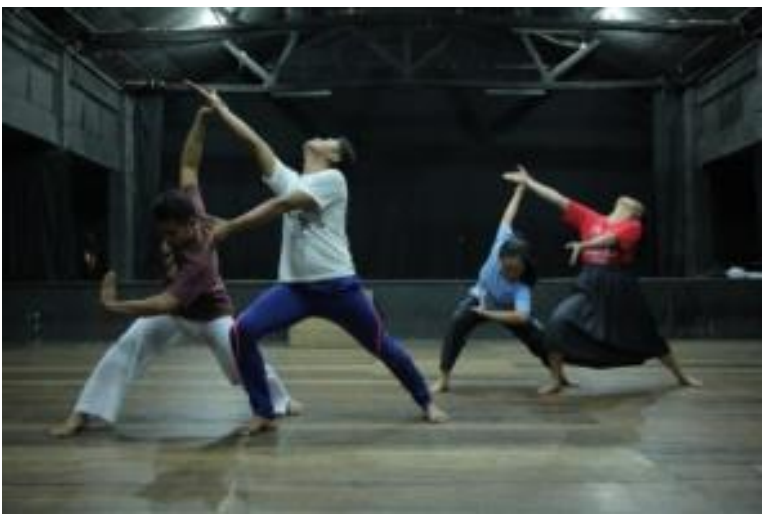

Gambar 4

Proses Latihan Dalam Bentuk Kesatuan Gerak

Menurut Loravianti karya ini diawali dengan aktifitas pemusik yang masuk dan penari dari samping panggung. Berbagai aktifitas kaum perempuan Minangkabau yang sedang membawa rantang, kemudian dilanjutkan dengan suasana seorang tokoh Bundo Kanduang yang menggendong bayi (Loravianti, 2017:89). Aktifitas yang digambarkan melalui gerakgerak keseharian perempuan dalam kehidupan sebagai perempuan Minangkabau.
Gorga : Jurnal Seni Rupa

Volume 10 Nomor 02 Juli-Desember 2021 p-ISSN: 2301-5942 | e-ISSN: 2580-2380

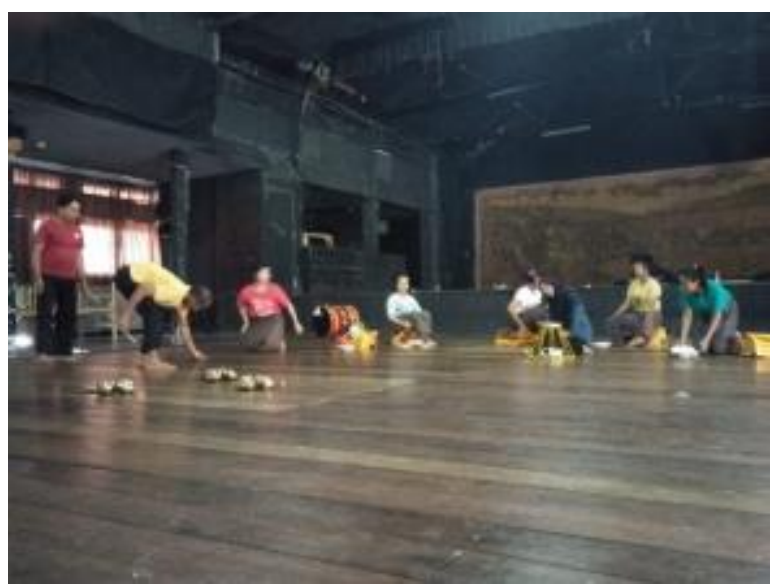

Gambar 5.

Aktifitas Penari dan Pemusik

Konstruksi akhir pada karya tari balega di tanah manang karya ketiga tahun 2019 gambaran perhelatan melalui rundiang rang dapua, diawali dengan keinginan sang anak pada sang ibu hingga menyampaikannya pada seluruh keluarga. Majapuik kato putuih, proses persiapan sebuah perhelatan yang senantiasa dilakukan oleh perempuan Minangkabau. Kemudian, babisiak ka nan dakek, mamanggia ka nan jauah gambaran tentang proses perhelatan dalam budaya Minangkabau. Mengeksplorasi berbagai perhiasaan penanda utama kaum perempuan Minangkabau. Menurut Wendy sebagai dramaturg, yang merancang kontruksi dramaturgi mengatakan bahwa menghadirkan berbagai properti yang ada menjadi suatu kebaruan yang berkembang pada masa ini atas hiasan pada tubuh perempuan. Cenderung menggambarkan tentang laku dan perilaku perempuan Minangkabau (Wawancara Wendy, Kamis, 29 Juli 2021, Rancangan Dramaturgi, Padangpanjang).

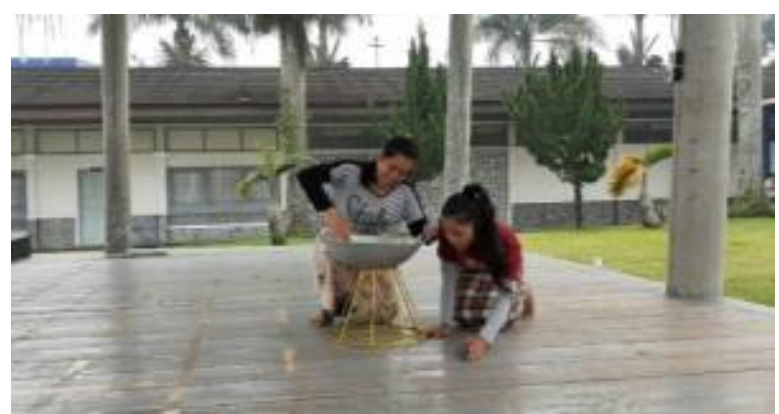

Gambar 6.

Aktifitas Persiapan Perhelatan

Dalam pembentukan tahap integrasi diperlukan untuk menghasilkan bentuk dimana, berbagai unsur pendukung pementasan disatukan satu sama lain. Integrasi berarti membuat unsur-unsur tertentu menjadi satu kesatuan yang bulat dan utuh (Puspito, 1989:375). Berdasarkan pengertian integrasi dapat disimpulkan bahwa integrasi dalam karya tari Balega Di Tanah 
Gorga : Jurnal Seni Rupa

Volume 10 Nomor 02 Juli-Desember 2021

p-ISSN: 2301-5942 | e-ISSN: 2580-2380

Manang dapat dilihat antara tari, musik dan ruang. Tari Balega Di Tanah Manang merupakan pertunjukan yang didukung oleh teknologi musik, dan visual multimedia, yang diharapkan dapat mewakili penggambaran dari peristiwa masa lalu sampai pada kenyataan pada saat ini.

Hal yang ada pada tari Balega Di Tanah Manang menurut Wendy memakai unsur teaterikal yang diintegrasi pada bagian bagian karya seperti adanya dialog pada akhir pertunjukan balega di tanah manang karya pertama tahun 2017, kemudian adanya suara atau himbauan dialog dari para penari juga dapat dilihat pada karya balega di tanah manang karya kedua tahun 2018 dan ketiga tahun 2019 (Wawancara Wendy, Kamis, 29 Juli 2021, Rancangan Dramaturgi, Padangpanjang). Berisikan tentang menunjukan posisi kaum perempuan sebagai pihak yang memiliki suara untuk melakukan kritikan terhadap budaya diam dan fetisisme perempuan, menjadi kesan muncul oleh budaya tari

Keterlibatan berbagai elemen artistik yang dihubungkan satu sama lain dalam tahapan integrasi ini, sekaligus diharapkan dapat merefleksikan kebutuhan pertunjukan kontemporer. Loravianti menyadari bahwa pengertian seni kontemporer berbagai batasan-batasan tegas antara berbagai genre seni telah demikian kabur, digantikan dengan garis putus-putus. Terbuka bagi berbagai kemungkinan (Loravianti, 2017:91).

Tahap persiapan pertunjukan juga menjadi ruang untuk mengkordinasikan berbagai unsur yang terlibat dalam pertunjukan, keamanan lokasi pertunjukan. Tahapan ini juga dimaksudkan untuk mengantisipasi kemungkinankemungkinan yang dapat mengganggu jalannya pertunjukan, antara lain cuaca dan suasana lingkungan lokasi pertunjukan. Tahapan ini dimulai dengan pengolahan ruang pergelaran agar memiliki tampilan yang artistik.

Pergelaran karya tari Balega Di Tanah Manang sebagai muara dari proses yang telah dilakukan selama berbulan-bulan. Pergelaran dilaksanakan pada malam hari setelah waktu shalat isya sesuai dengan jadwal undangan yang telah diberikan oleh panitia penyelenggara pertunjukan. Disisi waktu yang diberikan juga memberikan keuntungan bahwa pada waktu malam penonton dilokasi pertunjukan memiliki waktu luang, sementara pada pagi hari hingga sorenya mereka bekerja.

\section{(5). Evaluasi pada Proses Penggarapan}

Penciptaan karya tari Balega Di Tanah Manang dilakukan dengan sistem kerangka dasar artinya secara keseluruhan struktur tari dibentuk menurut bagianbagian atau adegan- adegan yang ditetapkan melalui dramaturgi tari. Wendy mengatakan bahwa dirinya ikut terlibat dalam membuat dan menuliskan struktur, dalam alur melalui dramaturgi, sehingga dapat menghadirkan dramatika melalui gerak, potensi utama kepada kecepatan dan kekuatan silek. (Wawancara Wendy, Kamis, 29 Juli 2021, Rancangan Dramaturgi, Padangpanjang).

Setelah terbentuk kerangka dasar dan pembagian waktu serta suasana kemudian di evaluasi bagian-bagian yang tidak sesuai dengan yang diharapkan. Hal ini dilakukan Wendy dan Loravianti secara bersama melalui tugas mereka masing-masing. Loravianti menjelaskan hal yang dilakukannya mengurangi atau menambah gerakan dan pola garapan disetiap gerak dan ruang penari. Kemudian menerima pendapat-pendapat terhadap apa yang disampaikan wendy agar terciptanya dramatika dalam karya tari Balega Di Tanah Manang dan evaluasi dilakukan diakhir proses latihan (Wawancara Loravianti, Sabtu, 31 Juli 2021, Kerangka Karya, Padangpanjang).

Evaluasi dengan cara duduk bersama setelah latihan dan Loravianti mulai melakukan koreksi terhadap karya keseluruhan dan kerampakan, kualitas gerak, emosi dan ekspresi penari. Begitu juga dengan Wendy melakukan evaluasi terhadap keseluruhan karya dan evaluasi melalui dialog antara dirinya dan Loravianti. Wendy mengatakan bahwa selalu memberikan stimulus kepada Loravianti agar imajinasinya berkembang, kemudian untuk perfomer memberikan pemahaman tentang porsi masing masing dalam keterlibatannya pada karya tari Balega Di Tanah Manang. disini performer harus paham, ada laku yang dilakukan secara mendalam.

Tari Balega Di Tanah Manang merupakan hasil reinterpretasi penggarapan terhadap fenomena, sejarah, dan realitas perempuan minangkabau masa kini. Nilainilai tersebut didasari oleh pembacaan atas fenomena dan sejarah yang menghasilkan pemahaman atas tiga hal. Pertama, perempuan Minangkabau masa kini harus melihat bahwa perubahan konstalasi sosial budaya, membuat mereka harus secara kritis membaca ulang posisi mereka dalam tatanan sosial kultural masyarakat matrilineal Minangkabau. Kedua, berbagai perubahan konstalasi sosial budaya pada prinsipnya mengubah pola tampilan perempuan Minangkabau, namun secara hakikat posisi ideal sebagai simpul kehidupan matrilineal tidak harus berubah total melainkan harus 
Gorga : Jurnal Seni Rupa

Volume 10 Nomor 02 Juli-Desember 2021

p-ISSN: 2301-5942 | e-ISSN: 2580-2380

secara cerdas disesuaikan. Ketiga, sebagai implikasinya, posisi ideal perempuan Minangkabau masa kini adalah kembali pada fitrahnya paling dasar, yakni sebagai ibu dari anak-anaknya. Artinya perempuan Minangkabau harus melihat tugas untuk menjadi pendidik dan pembimbing generasi yang lebih muda sebagai posisi mereka yang paling penting dalam masyarakat Minangkabau masa kini.

Gagasan koreografer dalam menciptakan sebuah karya pun melalui proses dramaturgi sehingga menghasilkan sebuah karya yang akan disampaikan kepada penonton. Karya Tari Balega Di Tanah Manang merupakan upaya mengekspresikan situasi dan kondisi masyarakat Minangkabau dalam tatanan matrilinial. Di Minangkabau matrilineal merupakan salah satu aspek utama dalam mendefinisikan identitas masyarakat Minang. Adat dan budaya mereka menempatkan pihak perempuan bertindak sebagai pewaris harta pusaka dan kekerabatan, Garis keturunan yang diwarisi melalu garis keturunan ibu kandung. Tatanan matrilinial inilah menjadi pengembangan laku, gerak dan bunyi yang berdasarkan pada tradisi silat sebagai pola ekspresi untuk pertunjukan kontemporer dalam karya tari Balega Di Tanah Manang.

\section{Pembahasan}

\section{1). Proses Dramaturgi Tari}

Proses perwujudan karya dapat dilihat melalui langkahlangkah yang dilakukan oleh koreografer dalam setiap mencipta. Namun dalam karya tari Balega Di Tanah Manang proses penciptaan karya diwujudkan melalui dua perspektif yaitu proses yang dilalui koreografer yang berdiskusi dengan dramaturg. Karya ini proses penciptaan karya lebih memaparkan tentang proses kerja dialog dalam mewujudkan ide /gagasan melalui pelahirannya dan proses itu terjadi, dilihat pada penari, pemusik, artistik dan yang terlibat lainnya. Gagasan yang membahas tentang perempuan Minangkabau melalui tatanan matrilineal ini berbeda dengan proses penciptaan karya lain. Dapat dilihat pada dramaturginya, karena Loravianti berargumen bahwa imajinasi yang diciptakan olehnya dibantu dengan dramaturgi oleh dramaturg Wendy dalam membuat alur dramatik adanya suasana, capaian pesan yang harus ada (Wawancara Loravianti, Jumat, 23 Oktober 2020 , Penciptaan Karya, Padangpanjang).

"Laurence Louppe berpandangan bahwa dalam proses kolaboratif seorang koreografer dalam komposisi mengatur jalannya situasi kelompok dan individu dalam melatih tubuh melahirkan gerak, dimana proses yang berusaha untuk melibatkan keinginan dan menciptakan ruang penemuan hal hal baru dalam proses penciptaan karya tari. Sedangkan dramaturg berpartisipasi dalam proses tersebut tanpa merubah tarian atau koreografi dalam suatu karya. Ia berpartisipasi sebagai peserta, mengamati dan merasakan bagaimana materi diproduksi; pada saat yang sama, dia juga terlibat dalam mendiskusikan, menyarankan, dan mengusulkan gambar dan gagasan, sehingga berkontribusi pada proses penciptaan" (Hansen dan Dracey, 2015:42).

Berdasarkan pemaparan diatas, dapat dilihat bahwa dalam dialog yang dilakukan Loravianti dengan Wendy dapat menghasilkan langkah-langkah yang ingin dilakukan dalam pelahiran ide garapan.

\section{(1). Penyampaian Konsep dan Tema Garapan}

Dalam penyampaian konsep dan tema garapan ini dilakukan dengan memberikan penjelasan secara lisan, sesuatu yang akan dikomunikasikan berkaitan dengan tema tari tentang tatanan matrilineal. Loravianti mengatakan bahwa Penyampaian konsep dan tema garapan itu dilakukan diawal pertemuan sebelum proses latihan kepada penari dan semua tim agar paham dengan konsep dalam garapan (Wawancara Loravianti, Sabtu, 31 Juli 2021, Konsep Garapan, Padangpanjang).

Konsep ini diharapkan mampu diterjemahkan dalam gerak tari, sehingga suasana yang dihadirkan dalam garapan tari dapat menyentuh jiwa penikmatnya. Penyampaian konsep ini juga memberikan pengertian kerjasama kepada para pendukung. Penjelasan yang dilakukan Loravianti meliputi tentang kerampakan gerak jika gerak dilakukan bersama-sama, hafalan, pola lantai, ekspresi, tanggung jawab dan rasa percaya diri, sehingga konsep dan tema garapan tari balega di tanah manang dapat diungkapkan secara utuh.

\section{(2). Pemberian Materi Garapan}

Pemberian materi garapan yang dilakukan Loravianti dalam karya tari Balega Di Tanah Manang melalui beberapa tahapan. Cara ini dilakukan agar dapat membantu memahami teori dan praktek gerak-gerak yang disampaikan.

\section{a. Teori}

Pemberian materi garapan secara teori dilakukan dengan memberikan penjelasan tentang teknik yang berkaitan dengan anggota tubuh yang akan digerakkan agar makna dan maksud dari gerak itu dapat dilakukan dengan baik. Hal ini juga terkait dengan penjelasan terhadap nama-nama gerak yang akan dipakai dan pola-pola gerak yang akan dikembangkan. Melalui wawancara dengan 
Loravianti mengatakan bahwa melakukan kegiatan penjelasan dan pemahaman gerak agar penari paham tentang teknik dasar gerak dan nama-nama gerak tradisi Minangkabau. Seperti silek sebagai pijakan dasar dalam berkarya, kemudian pijakan dasar tari tradisi Minang dan pengembangannya.

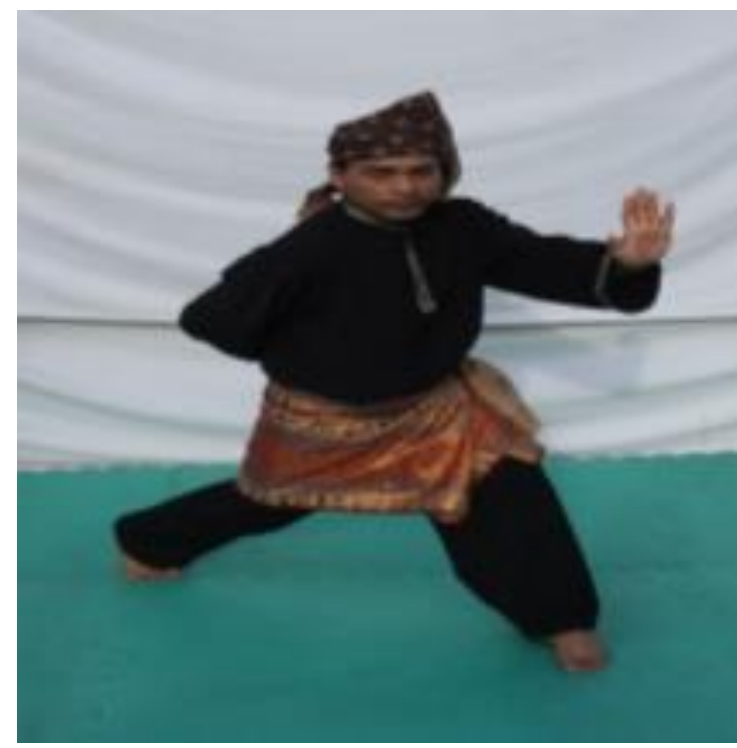

Gambar 7.

Teknik Dasar Gerak silek

Berdasarkan gambar di atas, salah satu contoh teknik dasar gerak silek pauah minangkabau. Silek ini nanti akan dikembangkan sesuai praktik kepada para penari.

\section{b. Praktik}

Praktik atau cara ini berkaitan langsung dengan teknik gerak dari materi gerak, diperlihatkan secara terperinci dan cermat. Bagaimana bentuk dan desainnya, proses alur gerak, volume gerak, kemudian langsung dilakukan oleh penari. Hal ini dilakukan berulang-ulang sampai penari merasa pas melakukannya.

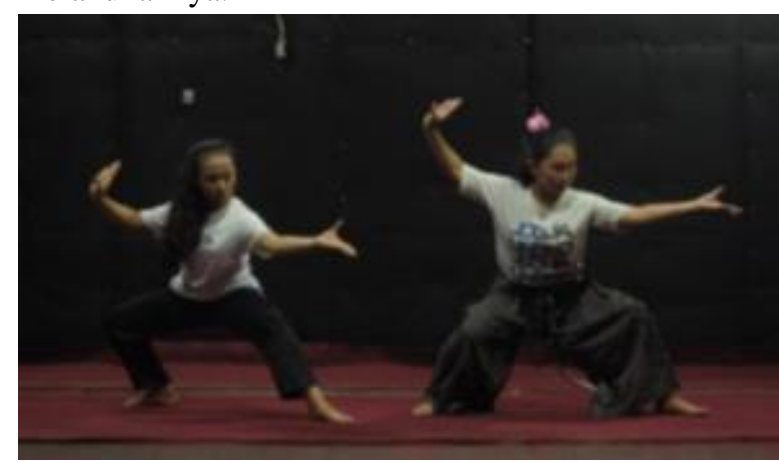

Gambar 8.

Bentuk Pengembangan Gerak Silek Pauah pada Penari

Pada gambar diatas terlihat bagaimana bentuk penari dalam mengaplikasikan gerak yang diberikan Loravianti agar dapat memberikan pola alur gerak,
Gorga : Jurnal Seni Rupa

Volume 10 Nomor 02 Juli-Desember 2021 p-ISSN: 2301-5942 | e-ISSN: 2580-2380

bentuk tubuh yang baik dalam melakukan gerak tersebut. Loravianti mengatakan bahwa ketika memberikan gerakan Loravianti mencoba menirukan gerakan pengembangan tersebut dan dipraktekkan langsung oleh penari, melalui arahan dan rangsangan dari dirinya sendiri sebagai koreografer.

\section{c. Proses Latihan}

Proses latihan dilakukan melalui pemilihan jadwal latihan. Proses ini dilalui melalui proses penciptaan dengan memformulasikan teknik dasar gerak khas minangkabau. Proses latihan ini dilalui melalui.

\section{a). Teknik Dasar Kekuatan Gerak Tubuh}

Teknik ini pada proses latihan bertolak dari posisi dasar ketubuhan dalam tradisi silek Minangkabau yang disebut kudo-kudo. Melalui posisi dasar inilah kemudian dapat ditelusuri sumber kekuatan tubuh dalam silek yang kemudian akan diformulasikan sebagai teknik kekuatan gerak tubuh Minang. Loravianti mengatakan bahwa memberikan teknik dasar kekuatan gerak tubuh Minang dilakukan agar penari dapat mencari karakter tubuh sehingga mampu merasakan gerak tersebut dalam dirinya.

Pemberian teknik dasar kekuatan gerak tubuh Minangkabau ini dilakukan oleh Loravianti sendiri sebagai koreografer kepada penarinya. Kemudian tugas sebagai dramaturg pun dilakukan dengan memberikan stimulus kepada Loravianti oleh Wendy, sehingga tubuh yang bergerak itu melahirkan bunyi dan dramatika. Dramaturgi dalam Tari Balega Di Tanah Manang secara konseptual tidak lagi koreografi yang konvensional, tidak lagi basic utamanya tubuh yang bergerak indah tetapi memberikan pemahaman tentang tubuh yang bergerak sekaligus berbunyi dan dramatik, bebunyian yang menangkap makna. Seperti penuturannya sebagai berikut: "pelahiran dramatika itu tergantung emosi penari. Darimana emosi muncul itu melalui pemahaman konseptual. Capaian dramaturgi konseptual lebih kepada emosi penari, bukan hapalan. Contoh ketika bergerak tidak dengan menghitung gerakan pada umumnya, tapi mencoba memberikan stimulus agar penari dapat berekspresi dengan ruang yang ada. Melawan konvensional yang ada, yang dibutuhkan adalah kuantitas penari selain dari kualitas. Gerak itu lebih kepola laku yang laku spesifik. Tubuh yang berbunyi. Contohnya unsur bunyi pada gerak, pakaian dan koreografi musikal dan teaterikal. Basis utamanya tidak lagi tubuh yang bergerak indah melainkan tubuh yang bergerak sekaligus berbunyi" (Wawancara Wendy, Kamis, 29 Juli 2021, Teknik Gerak, Padangpanjang). 
Berdasarkan penuturan Wendy tersebut, dapat dilihat bahwa proses dramaturgi yang diciptakannya lebih kepada dramaturgi konseptual, memahami pemaknaan dari emosi penari yang bebas berekspresi yang diatur oleh koreografer. Dramatik yang hadir melalui gerak penari yang didorong oleh musik yang menyatu dengan gerak dan ekspresi penari. Bentuk dramaturginya pun diharapkan Wendy lebih berpola musikal dan teaterikal, maksudnya disini tubuh penari menghasilkan bunyi, menghadirkan gerak natural dalam laku keseharian sehingga pola koreografi dalam tari Balega Di Tanah Manang tidak mengarah pada pola koreografi konvensional, tetapi lebih memaknai sehingga dapat dirasakan oleh penonton.

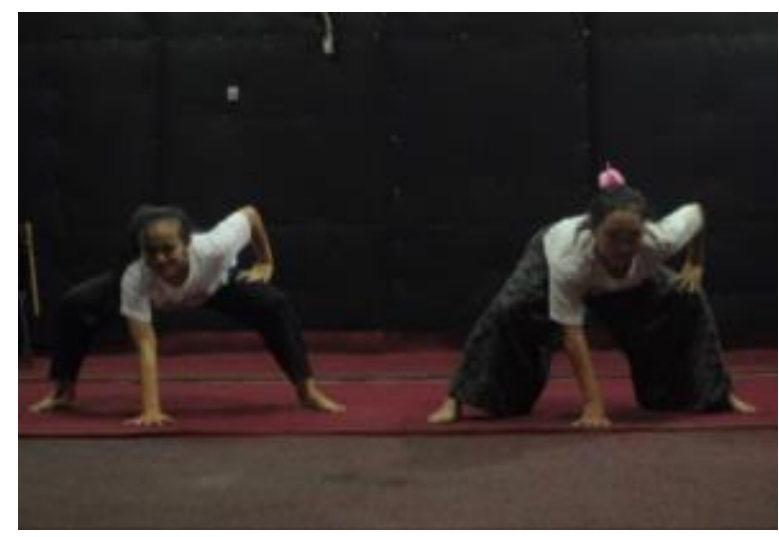

Gambar 9.

Proses Latihan Gerak Dasar Silek pada Balega di Tanah Manang Karya Pertama

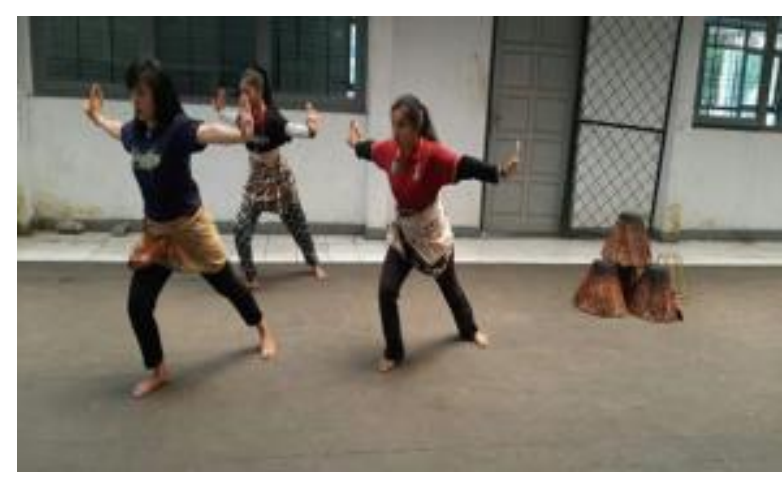

Gambar 10.

Proses Latihan Gerak pada

Balega Di Tanah Manang karya ketiga

\section{b). Teknik Dasar Ketahanan Gerak Tubuh}

Bertolak dari sisitem pernafasan dan sistem penyaluran energi dalam gerak tubuh yang biasa dilakukan dalam tradisi silek. Menurut Loravianti upaya melakukan pernafasan yang normal dalam melakukan gerak. Nafas adalah daya tahan utama dalam gerak. Pelatihannya dilakukan dengan hitungan mengambil nafas, menahan nafas dalam diafragma dan mengeluarkannya melalui hidung. Contohnya ketika mengambil nafas dalam hitungan 7
Gorga : Jurnal Seni Rupa

Volume 10 Nomor 02 Juli-Desember 2021

p-ISSN: 2301-5942 | e-ISSN: 2580-2380

maka menahannya pun dalam hitungan 7 termasuk mengeluarkan nafas. Pernafasan ini diawali dalam posisi kudo-kudo dengan bergerak secara perlahan dan dilanjutkan dengan gerak yang agak cepat. Melalui kesadaran pernafasan yang ada, dapat diterapkan kesadaran penyaluran energi yang ada dalam tubuh.

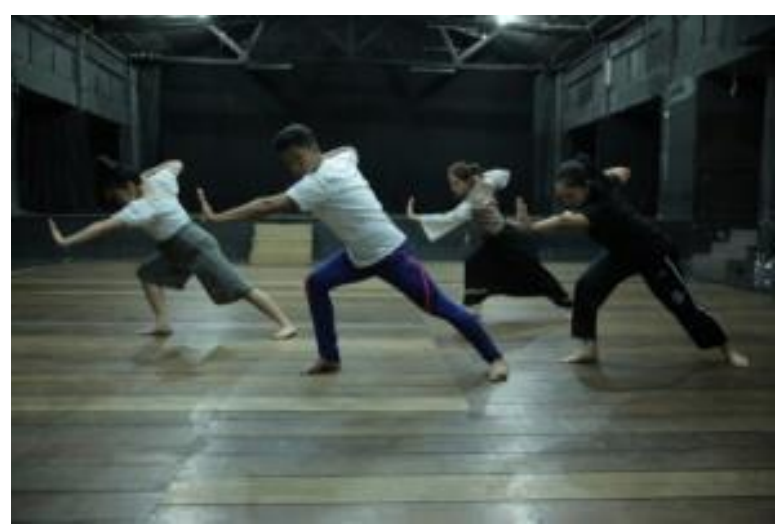

Gambar 11.

Proses Gerak Dalam Ketahanan Tubuh pada Tari Balega di Tanah Manang Karya Pertama

Berdasarkan gambar diatas ketahanan gerak pada posisi tubuh yang bertumpu pada kaki kanan arah samping kanan dan kaki kiri lurus arah kiri kemudian arah badan kesamping kanan dengan fokus kesamping kanan. Tangan kiri diarahkan kesamping kanan dan tangan kiri ditekuk. Gerakan ini berupaya agar penari dapat memiliki ketahanan gerak pada tubuh sehingga ketika melakukan beberapa gerakan nantinya dapat menyeimbangi kekuatan pada gerak selanjutnya.

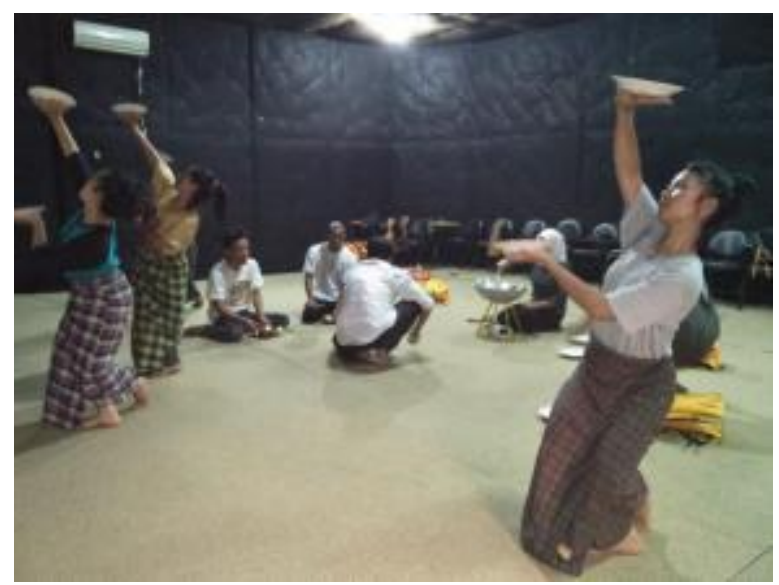

Gambar 12.

Proses Gerak Ketahanan pada Tari Balega di Tanah Manang Karya Kedua

Posisi badan arah kedepan dengan kaki disilang dan ditekuk tangan kanan arah keatas dan tangan kiri sejajar dada menggunakan properti piring. Terlihat penari bergerak menggunakan kain sebagai pakaian, 


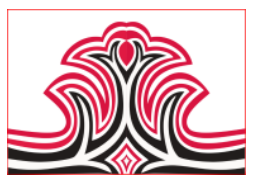

sehingga gerak silek yang dilahirkan pun bisa menyesuaikan kodek atau kain untuk pakaian bagian bawah. Melihat seberapa besar ruang yang terlahir pada gerak menggunakan kain.

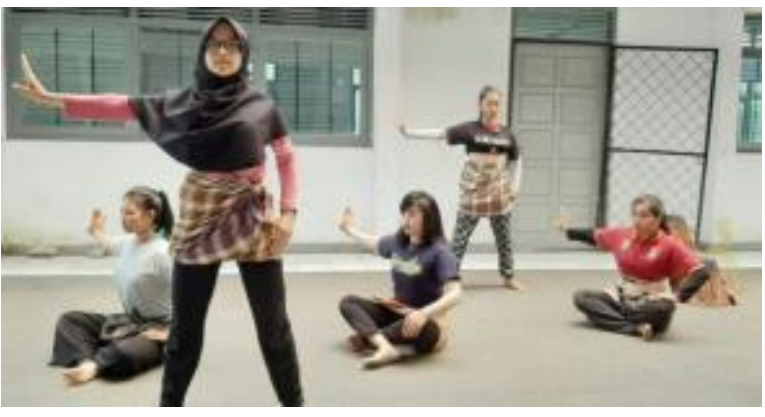

Gambar 13.

Proses Gerak Ketahanan pada Tari Balega di Tanah Manang Karya Ketiga

Posisi beberapa penari dengan berdiri dan duduk, pertahanan kekuatan yang bertumpu pada kaki bagi penari yang berdiri. Tangan kanan lurus kesamping dengan arah badan kedepan.

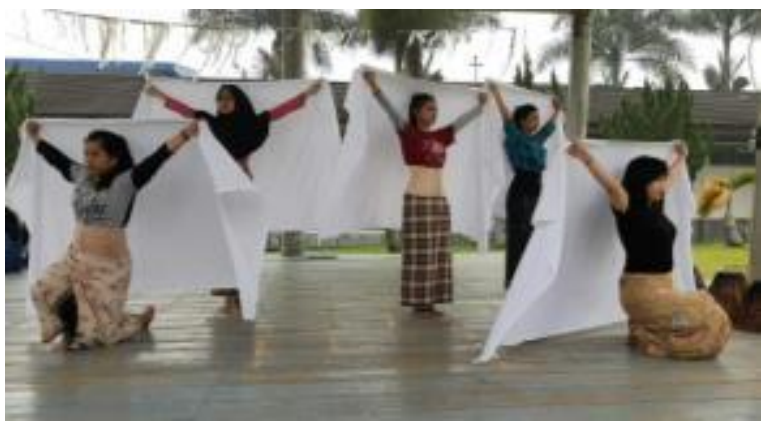

Gambar 14.

Proses Ketahanan Gerak Tari Balega di Tanah Manang Karya Ketiga

Proses latihan ini menggambarkan bahwa mempelajari ketahan gerak pada lengan dan tungkai. Dimana terlihat posisi badan yang bertumpu pada salah satu kaki dengan posisi setengah duduk dan lengan yang menahan dengan posisi melebar dan arah pandang lurus kedepan.

\section{c). Teknik Dasar Dinamika Gerak Tubuh}

Teknik ini merupakan upaya menerapkan kesadaran atas tingkatan gerak (atas,sedang dan bawah), kecepatan gerak (pelan, sedang dan cepat), dan irama gerak (gabungan antara tingkatan dan kecepatan gerak). Latihan ini dilakukan dengan tingkatan gerak bawah, naik menjadi tingkatan sedang, lanjut pada gerakan tingkat atas. Pada koreografi tari Balega Di Tanah Manang teknik dasar ini perlu untuk membangun gerakan yang ritmis dan indah, namun perlu makna yang terlahir pada setiap gerakan.
Gorga : Jurnal Seni Rupa

Volume 10 Nomor 02 Juli-Desember 2021 p-ISSN: 2301-5942 | e-ISSN: 2580-2380

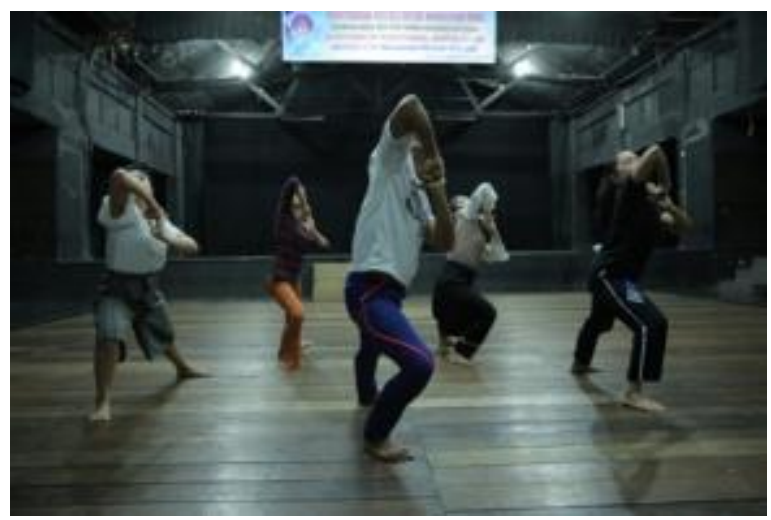

Gambar 15.

Proses Gerak Dinamika pada Tari Balega di Tanah Manang Karya Pertama

Berdasarkan gerak diatas merupakan salah satu gerak dengan posisi badan condong kedepan dengan fokus badan samping dan tangan kanan menyiku kedepan arah atas, kaki kiri lurus panjang kebelakang. Disini dilihat bahwa posisi badan penari haruslah sesuai dengan yang diarahkan oleh koreografer. Arah pandang dengan melihat kesiku tangan yang berlevel tinggi. Ketahanan penari dalam memainkan dinamika gerak sangat diharapkan agar mendapat hasil maksimal.

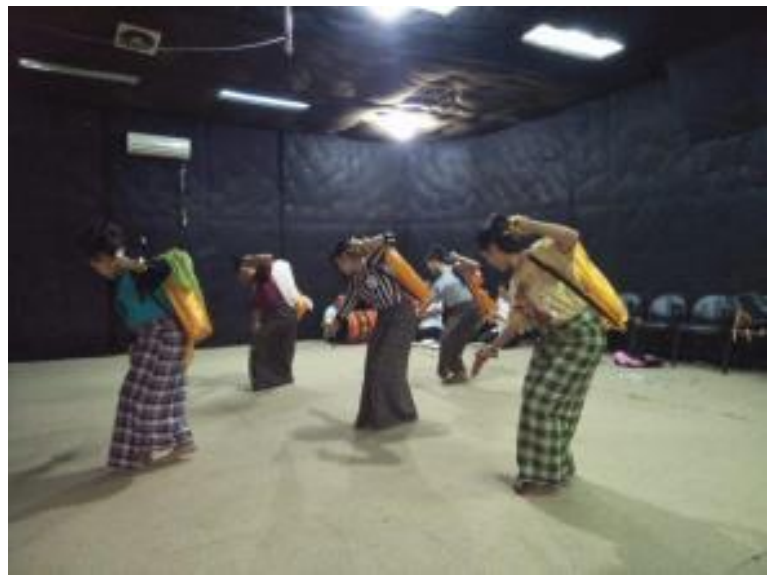

Gambar 16.

Proses Gerak Dinamika pada Tari Balega di Tanah Manang Karya Kedua

Berdasarkan proses latihan diatas dapat dilihat bahwa posisi badan sedang kedua kaki ditekuk silang kanan depan kiri belakang, arah badan kedepan dengan fokus pandangan kebawah arah diagonal kanan mengikuti tagan kanan yang ditusuk kebawah dan tangan kiri ditekuk dengan siku menghadap diagonal belakang kiri. Dalam gerak ini memperlihatkan posisi penari yang menyelaraskan gerak sehingga mempunyai posisi tubuh yang sama. 


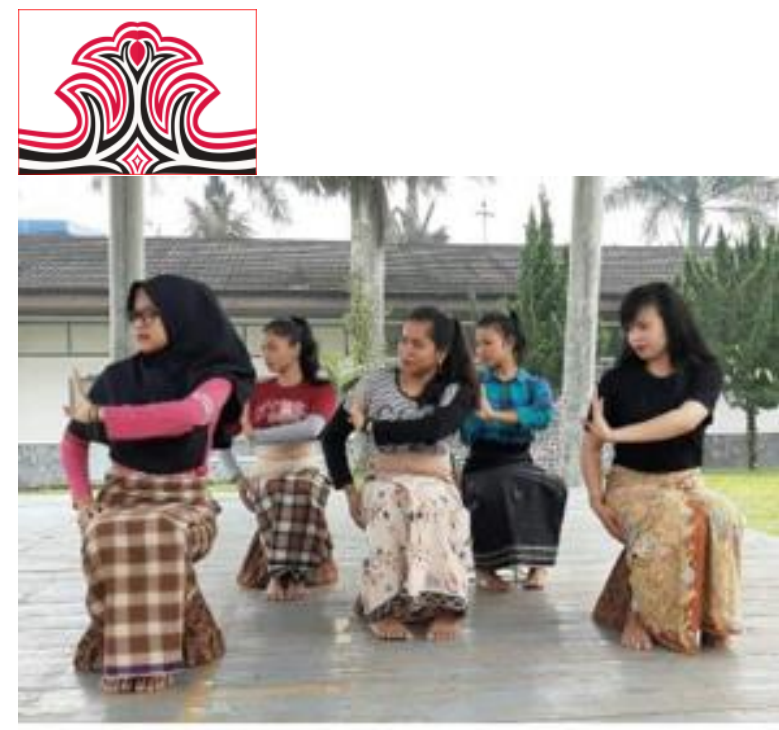

Gambar 17.

Proses Gerak Dinamika pada Tari Balega di Tanah Manang Karya Ketiga

Gambar di atas memposisikan level rendah dengan penari duduk diatas properti dengan badan tegap arah depan dan pandangan difokukan kesamping, tangan kiri ditekuk arah dada dan tangan kanan berada disamping badan.

\section{d). Teknik Dasar Estetika Gerak Tubuh}

Teknik ini merupakan upaya melakukan gerakan berdasarkan elemen Gelek dan Balabeh dalam tradisi silek di Minangkabau. Gelek yang merupakan menghindarkan serangan lawan dalam tradisi silek. Balabeh merupakan upaya atraktif untuk memulai suatu serangan atau upaya persiapan untuk melakukan pertahanan atas kemampuan lawan. Inilah nanti yang akan ditransformasikan menjadi teknik estetika gerak tubuh Minangkabau untuk seni pertunjukan Balega Di Tanah Manang. Proses latihan ini menurut Loravianti mengenali kemampuan ekspresi mata yang di sesuaikan dengan dinamika gerak. Adanya arah pandang dan ekspresi wajah merupakan salah satu kunci utama yang terkait erat dengan gerak dalam tradisi silek (Wawancara Loravianti, Padangpanjang 31 Juli 2021).

Proses dramaturgi dalam praktik yang dilakukan Loravianti dan Wendy merupakan bentuk diskusi yang dilakukan. Menyatukan pandangan pandangan dalam proses penciptaan, membagi tugas-tugas dalam peranannya. Menciptakan penari yang dapat mengenali tubuhnya sendiri dalam proses sehingga melalui pengalaman-pengalaman tubuh yang dipengaruhi gerak dasar Minangkabau yang diarahkan oleh koreografer, kemudian dramaturg memberikan stimulus dalam pemaknaan setiap gerak yang dilahirkan. Bertolak dari apa yang menjadi kesadaran pemikiran, proses dramaturgi tari Balega Di Tanah Manang berlandaskan pada pemikiran upaya pengembangan pola artistik melalui kajian-
Gorga : Jurnal Seni Rupa

Volume 10 Nomor 02 Juli-Desember 2021 p-ISSN: 2301-5942 | e-ISSN: 2580-2380

kajian atas gerak tarian Minangkabau yang berdasarkan dari gerak Silek sebagai dasar dramatika pertunjukannya.

\section{KESIMPULAN DAN SARAN}

\section{Kesimpulan}

Berdasarkan hasil penelitian tentang praktik dramaturgi tari dalam penciptaan Balega Di Tanah Manang, karya Susas Rita Loravianti. Dapat disimpulkan bahwa Susas Rita Loravianti atau yang akrab dipanggil dengan Loravianti adalah salah satu koreografer Minangkabau Sumatera Barat, melalui pengalamannya dan sebagai seorang perempuan Minangkabau mengantarkan karya-karya yang diciptakannya kepada persoalan-persoalan perempuan Minangkabau. Pengalaman ini menjadikan suatu komitmen di dalam menciptakan sebuah ide untuk capaian sebuah karya tari. melihat persoalan perempuan Minangkabau melalui sudut pandang yang berbeda pada setiap karyanya.

Hal menarik juga dapat dilihat pada karya Loravianti yang berangkat dari perempuan Minangkabau adalah tari Balega Di Tanah Manang, karya tari ini merupakan karya yang pelahirannya memiliki tiga bentuk karya dengan satu konsep melalui peristiwa yang berbedabeda. Karya ini merupakan karya Hibah Multitahun Di Institut Seni Indonesia Padangpanjang. Memiliki ciri khas tersendiri dalam proses penciptaan karya loravianti dalam kesadarannya menghadirkan peran seorang dramaturg sebagai teman diskusi untuk membantunya dalam penggarapan. Hal inilah yang membedakan Loravianti dengan beberapa koreografer Minangkabau lainnya. Karya tari Balega Di Tanah Manang pun dalam pelahirannya melalui dramaturgi tari yang dibantu oleh seorang dramaturg yaitu Wendy Hs.

Dramaturgi tari melalui pergesekannya lahir karena adanya kebutuhan dalam proses penciptaan tari-tari kontemporer atau eksperimental, adanya kebutuhan untuk menggali ide-ide baru dan bentuk artistik yang baru. Proses demikian lah maka koreografer membutuhkan seorang partner kerja atau teman diskusi atau disebut dengan mata kedua dalam proses penciptaan karya. Disitulah kemudian peran dramaturg sebagai tim yang menjembatani praktek seseorang koreografer dengan teori. Dalam praktek dramaturgi tari seorang dramaturg tidak hanya menjembatani tetapi juga terlibat aktif didalam produksi tari.

Praktik dramaturgi dalam tari Balega Di Tanah Manang merupakan dramaturgi konseptual yang lebih melihat makna, dramatika yang dilahirkan gerak, laku 
sehingga karya tari dalam prosesnya tidak lagi bentuk konvensional pada umumnya. Penggarapan karya tari ini melihatkan keaktifan tubuh penari terhadap bunyi, pemahaman terhadap musikalitas penari dan pelahiran koreografi melalui emosi penari bukan hapalan. Praktik dialog yang dilakukan Loravianti dan Wendy pun dengan membagi peran masing-masing dalam setiap proses penciptaan. Loravianti dalam perannya memiliki ide dan menafsirkan gagasan kedalam pola koreografi sedangkan Wendy memiliki peran membantu dalam membuat konsep gagasan yang ditafsirnya melalui ide Loravianti kemudian membuatkan alur dramaturgi, tema, artistik, musikal dan teaterikal dalam pertunjukan, memberikan stimulus terhadap gerak sebagai dramatika. Pola kerja ini dapat dilihat melalui pandangan Pill Hansen bahwa dramaturg dalam artikulasi yang berbeda dari cara keterlibatan dan hubungan dramaturg pada tugas mewujudkan dalam konteks melalui peran sebagai kolaborasi, partisipasi, teman, pembimbing, pengkritik, pembantu, pengingat, dialog, navigasi dan banyak lainnya. Peran Wendy dapat dilihat melalui tugasnya sebagai dramaturg dalam tari Balega Di Tanah Manang. adanya praktik dialog yang dilakukan Wendy dan Loravianti dalam proses kerja dramaturginya.

\section{Saran}

Saran yang ingin disampaikan oleh penulis dalam penelitian ini lebih kepada proses kerja yang dilakukan antara koreografer dan dramaturg dalam melakukan proses penciptaan dramaturgi. Sepahaman peneliti, dramaturgi tari tidak hanya berbicara persoalan tentang proses kreatif namun adanya keterlibatan aktif seorang dramaturg didalam produksi tari dan akan mempermudah kinerja koreografer. melakukan diskusi pada sebelum dan sesudah latihan diantara koreografer dan dramaturg. Begitu juga dalam proses penciptaan karya koreografer harus didampingi oleh dramaturg selama proses latihan berlangsung, sehingga teori dengan praktik dramaturgi dapat diwujudkan dalam bentuk sesuai yang diinginkan. Untuk para pelaku seni pertunjukan apalagi seni tari. jika berkarya dalam proses penciptaan, sebaiknya menghadirkan teman diskusi yang ikut terlibat dalam memberikan rangsangan sehingga karya yang hadir pun dapat memiliki struktur dan tekstur karya yang tersusun.

\section{DAFTAR RUJUKAN}

Denzi, Norman K Dan Yvonna S. Lincoln (Eds). (2009). Handbook of Qualitative Research. Terj. Dariyatno Dkk. Yogyakarta: Pustaka Pelajar.

Hansen, Pil Dan Darcey Callison. (2015). Dance Dramaturgy: Modes Of Agency, Awareness And
Engagement. United Kingdom: Palgrave Macmillan.

Loravianti, Susas Rita. (2003). Karya Tari Perempuan Dalam Kaba. Laporan Karya. Padangpanjang : Isi Padangpanjang.

Loravianti, Susas Rita. (2014). Tari Garak Nagari

Perempuan. Laporan Karya. Surakarta: Isi Surakarta.

Loravianti. (2020). "Dramaturgi". Hasil Wawancara Pribadi: 23 Oktober 2020, Guguak Malintang.

Luckhurts, Mary. (2005). Dramaturgy: A Revolution In Theatre. New York: Cambrige University Press.

Mulyadi Seto, Dkk. (2019). Metode Penelitian Kualitatif Dan Mixed Method. Depok: PT. Rajagrafindo Persada.

Murgiyanto, Sal. (2016). Kritik Pertunjukan dan Pengalaman Keindahan. Jakarta: Penerbit Pascasarjana-Ikj (Institut Kesenian Jakarta).

Raihan. (2018). "Gerak Dinamika”. Hasil Dokumentasi Pribadi: 09 Juli 2018, Studio Tari ISI Padangpanjang.

Simatupang, Lono. (2013). Pergelaran : Sebuah Mozaik Penelitian Seni-Budaya. Yogyakarta : Jalasutra.

Sugiyono. (2007). Metode Penelitian Kuantitatif, Kualitatif Dan R\&D. Bandung: Alfabet.

Wulan, Sari Renee. (2019). Dramaturgi : Sesuatu Yang

Dekat. Https://Gelaran.Id/Dramaturgi-TariSesuatu-Yang-Dekat (diakses 30 Desember 2019).

Yudiaryani, dkk. .(2017). Karya Cipta Seni

Pertunjukan. Yogyakarta: JB Puplisher Bekerjasama Dengan Fakultas Seni Pertunjukan, Institut Seni Indonesia Yogyakarta. 